\title{
Mechanistic rationale for MCL1 inhibition during androgen deprivation therapy
}

\author{
Frédéric R. Santer ${ }^{1}$, Holger H. H. Erb ${ }^{1,2}$, Su Jung Oh ${ }^{1}$, Florian Handle ${ }^{1}$, Gertrud E. \\ Feiersinger $^{1}$, Birgit Luef ${ }^{1}$, Huajie Bu ${ }^{1}$, Georg Schäfer ${ }^{1}$, Christian Ploner ${ }^{3}$, Martina \\ Egger $^{1}$, Jayant K. Rane ${ }^{2}$, Norman J. Maitland ${ }^{2}$, Helmut Klocker ${ }^{1}$, Iris E. Eder ${ }^{1, *}$ and \\ Zoran Culig ${ }^{1, *}$ \\ ${ }^{1}$ Medical University of Innsbruck, Department of Urology, Division of Experimental Urology, Innsbruck, Austria \\ ${ }^{2}$ Yorkshire Cancer Research Unit, University of York, York, United Kingdom \\ ${ }^{3}$ Medical University of Innsbruck, Department of Plastic, Reconstructive \& Aesthetic Surgery, Innsbruck, Austria \\ * Joint senior authors \\ Correspondence to: Zoran Culig, email: zoran.culig@i-med.ac.at \\ Keywords: endocrine therapy, cell cycle arrest, cell death, treatment resistance, BCL2 family \\ Received: December 20,2014 Accepted: January 13,2015 Published: January 14, 2015
}

This is an open-access article distributed under the terms of the Creative Commons Attribution License, which permits unrestricted use, distribution, and reproduction in any medium, provided the original author and source are credited.

\section{ABSTRACT}

Androgen deprivation therapy induces apoptosis or cell cycle arrest in prostate cancer (PCa) cells. Here we set out to analyze whether MCL1, a known mediator of chemotherapy resistance regulates the cellular response to androgen withdrawal. Analysis of MCL1 protein and MRNA expression in PCa tissue and primary cell culture specimens of luminal and basal origin, respectively, reveals higher expression in cancerous tissue compared to benign origin. Using PCa cellular models in vitro and in vivo we show that MCL1 expression is upregulated in androgen-deprived PCa cells. Regulation of MCL1 through the AR signaling axis is indirectly mediated via a cell cycle-dependent mechanism. Using constructs downregulating or overexpressing MCL1 we demonstrate that expression of MCL1 prevents induction of apoptosis when PCa cells are grown under steroid-deprived conditions. The BH3-mimetic Obatoclax induces apoptosis and decreases MCL1 expression in androgen-sensitive PCa cells, while castration-resistant PCa cells are less sensitive and react with an upregulation of MCL1 expression. Synergistic effects of Obatoclax with androgen receptor inactivation can be observed. Moreover, clonogenicity of primary basal PCa cells is efficiently inhibited by Obatoclax. Altogether, our results suggest that MCL1 is a key molecule deciding over the fate of PCa cells upon inactivation of androgen receptor signaling.

\section{INTRODUCTION}

Androgen deprivation therapy (ADT) is a firstline therapy for locally advanced and metastatic prostate cancer (PCa). This includes the use of Gonadotropinreleasing hormone (Luteinizing-hormone releasing hormone) agonists and antagonists suppressing the production of testosterone, and non-steroidal antiandrogens (e.g. Bicalutamide $\left(\operatorname{Casodex}^{\mathrm{TM}}\right)$ ) that inhibit activation of the androgen receptor (AR) by competing with its natural ligand dihydrotestosterone [1]. Despite initial success, most patients experience progression within 12 to 33 months to a more aggressive phenotype termed castration-resistant $\mathrm{PCa}(\mathrm{CRPCa})$ concurrent with a reactivation of the AR signaling axis. ADT induces shrinkage of the tumor or stops its growth. On the cellular level, the consequences of ADT on malignant prostate epithelial cells are induction of apoptosis or cell cycle arrest in $\mathrm{G}_{1}$ phase [2]. Obviously, cells reacting with a cell cycle arrest and unable to induce apoptosis may be at the basis of development of castration resistance. Hence, in order to improve the efficiency of ADT, combination therapies are warranted where the ADT-additive therapy targets the $\mathrm{G}_{1}$ cell cycle-arrested PCa cells. 
We hypothesized that the molecular difference between the apoptosis- and cell cycle arrest- inducing effects of ADT could be found among members of the BCL2 protein family, which act as a rheostat regulating the balance between survival and apoptosis [3]. Pro-apoptotic proteins of this family commit cells to programmed death by permeabilising the outer mitochondrial membrane followed by cytochrome $\mathrm{C}$ release. MCL1 is a pro-survival member of the BCL2 family and prevents activation of pro-apoptotic BCL2-homology $(\mathrm{BH}) 3$-only proteins and the effector BAK1 [4]. MCL1 expression is induced by a number of cytokines and growth factors and is tightly regulated at transcriptional, post-transcriptional and posttranslational levels [5]. High protein expression levels and somatic copy-number amplifications of the MCL1 gene have been found in several cancer types [6]. MCL1 has superior apoptosis-inhibitory functions compared to other BCL2 family members [7]. It confers multi-drug resistance [8] and, moreover, resistance to ABT-737, a BH3-mimetic inhibiting anti-apoptotic BCL2 family members with the exception of MCL1 [9]. In contrast, Obatoclax (GX15070), which also targets MCL1, can overcome ABT-737mediated resistance [10]. Obatoclax has been assessed in clinical studies in combinatorial approaches with existing therapies [11-13].

Here, we demonstrate that high expression of MCL1 promotes the survival of steroid-deprived and cell cyclearrested PCa cells. Our data suggests that inhibition of MCL1 could improve currently used ADT protocols by targeting the $\mathrm{G}_{1}$ phase-arrested cell population.

\section{RESULTS}

\section{Increased expression of MCL1 in malignant compared to benign areas in prostate tissue specimens}

In order to assess expression of MCL1 in prostatic tissue and to validate MCL1 as a potential target for treatment of PCa we performed immunohistochemistry on tissue specimens from treatment-naïve prostate cancer (tnPCa) patients who underwent radical prostatectomy (Fig. 1A). A significantly increased staining score of cytoplasm-localized MCL1 could be observed in malignant compared to adjacent benign areas (Fig. 1A, detail views; Fig. 1B, left). However, we could not observe a positive correlation of MCL1 expression with Gleason score (Fig. 1B, right). Additionally, we analyzed MCL1 mRNA expression in primary basal, androgenindependent [14] cells grown from benign and malignant biopsies from tnPCa gained after radical prostatectomy (Fig. 1C). To determine whether MCL1 is differentially expressed with increasing cell differentiation, we separated committed basal $\left(\mathrm{CB}, \mathrm{CD} 49 \mathrm{~b}^{10}\right)$ from transit amplifying cells (TA, CD49b ${ }^{\text {hi }}$ ) based on their potential to attach to type I collagen. Consequently, stem/tumorinitiating cells (SC/TIC) were isolated from the TA population by making use of their CD133 expression [15]. MCL1 mRNA expression was then measured by qRT-PCR on isolated cell populations. We found that MCL1 mRNA is increasingly expressed in malignant compared to benign samples in SC/TIC and TA populations. Intriguingly, TIC showed highest increase of MCL1 mRNA expression levels compared to benign $\mathrm{SC}$, which could point to increased apoptotic resistance of TIC. Altogether, this showed that MCL1 expression is increased in basal and luminal prostatic compartments of cancerous compared to benign origin.

\section{Activation of the AR signaling axis leads to decreased MCL1 expression levels}

Next, we analyzed the role of AR signaling and androgen deprivation on MCL1 expression levels using established cell culture models of PCa. Surprisingly, AR inactivation through steroid deprivation (using 10\% charcoal-stripped serum, CSS) caused an increase of MCL1 in LNCaP and to a lesser extent in VCaP cells compared to normal growth conditions (10\% fetal calf serum, FCS) (Fig. 2A). This effect was lost in LNCaPabl, a derivative of the LNCaP cell line that has adapted to steroid-deprived conditions but has retained androgen sensitivity [16]. On the other hand, treatment with the synthetic androgen R1881 for $48 \mathrm{~h}$ decreased MCL1 expression in a concentration-dependent manner in the androgen-sensitive cell lines LNCaP, LNCaP-abl and VCaP. MCL1 expression in the AR-negative cell lines PC-3 and LNCaP-IL-6+ [17] did not decrease upon R1881 treatment. To confirm the involvement of AR in the regulation of MCL1, AR activity was inhibited by the anti-androgen Bicalutamide (Fig. 2B) or by knocking down its expression by means of siRNA specific for AR (Fig. 2C). In both cases decreased MCL1 expression through the action of R1881 could be antagonized, while AR-negative PC-3 were unaffected by Bicalutamide treatment. R1881 treatment was able to partly counteract the siRNA-mediated downregulation of AR. Analysis of explants from an in vivo experiment, where $\mathrm{LNCaP}$ were xenografted subcutaneously in male nude BALB/c mice, showed increased staining for MCL1 when animals were castrated compared to intact mice (Fig. 2D). Similarly, when intact animals bearing LNCaP or castrated animals bearing LNCaP-abl xenografts received injections with oligodeoxynucleotides (ODN) targeting AR, increased expression levels of MCL1 were observable (Fig. 2E).

To address the question whether androgenic repression of MCL1 is a transcriptional or posttranslational mechanism, we measured MCL1 mRNA levels $48 \mathrm{~h}$ after treatment with R1881 (Fig. 2F) and 
A

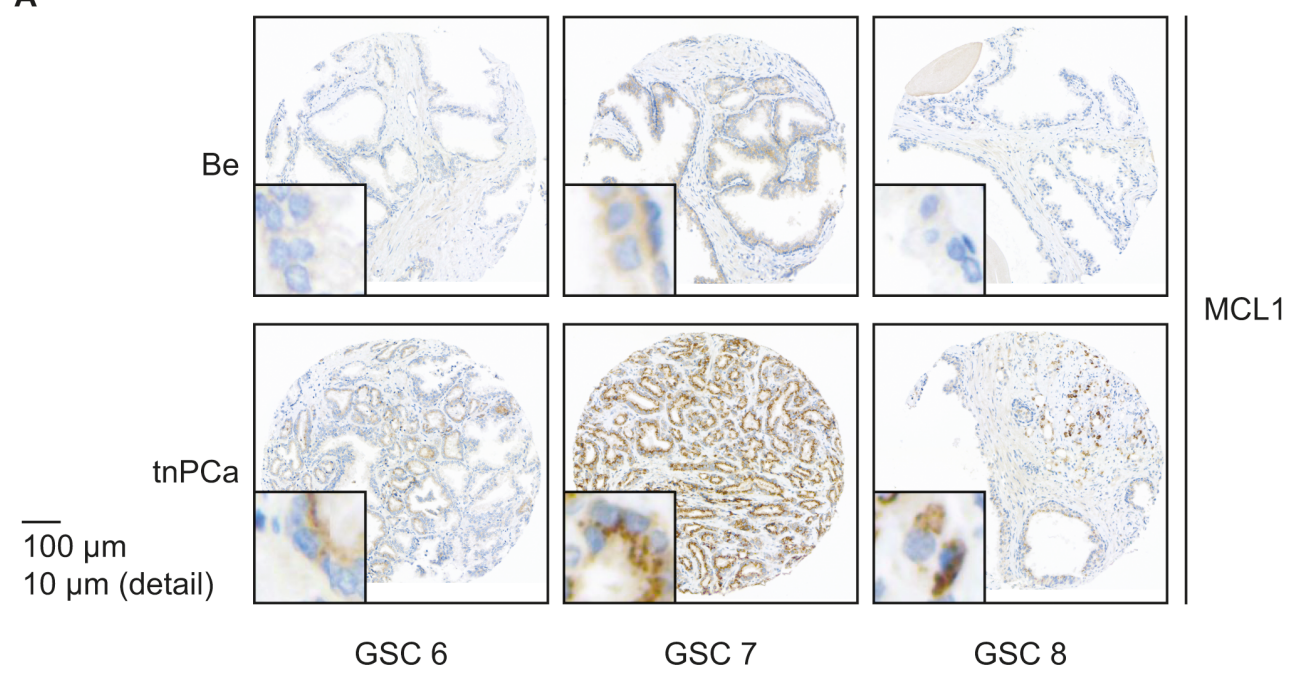

B

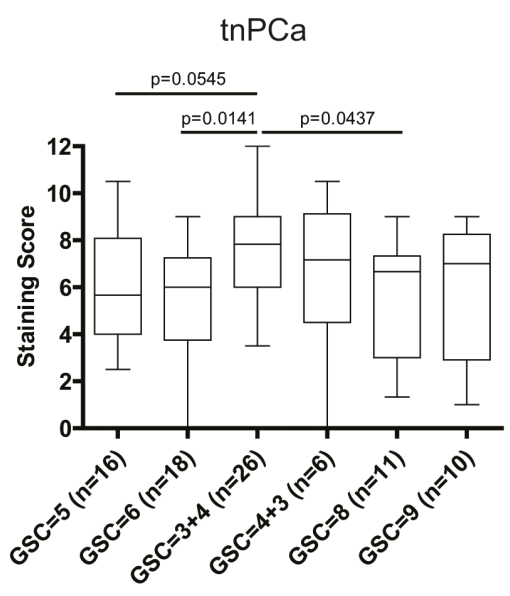

C

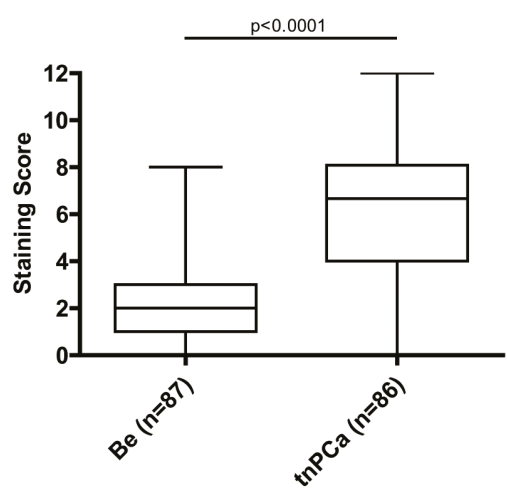

Stem/Tumor-initiating: (CD49b ${ }^{\text {hi }}$, CD133)

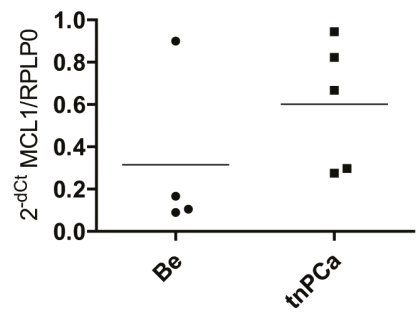

Transit amplifying:

$\left(C D 49 b^{\text {hi }}\right)$

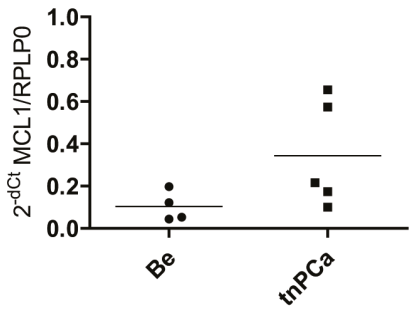

Committed basal: $\left(C D 49 b^{10}\right)$

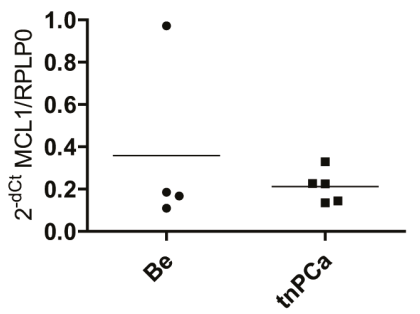

Figure 1: Increased expression of MCL1 in malignant areas of treatment-naïve prostate tissue. (A, B) Immunohistochemistry for MCL1 expression was performed on a TMA arranged with samples from treatment-naïve $\mathrm{PCa}$ (tnPCa) patients undergoing radical prostatectomy. Stainings from cancerous areas of 86 patients and adjacent benign areas of 87 patients were evaluable. (A) Representative images of positive MCL1 staining from paired tissue specimens of malignant areas (tnPCa) with Gleason Score (GSC) 6, 7 and 8, and adjacent benign areas (Be) are shown. (B) MCL1 staining was evaluated by an uropathologist using the quickscore system and the resulting staining scores are illustrated in box and whiskers graphs. (C) MCL1 mRNA expression was determined in primary basal benign and malignant cells after sorting into stem/tumor-initiating cell (SC/TIC, CD133+, CD49bhi), transit amplifying (TA, CD49bhi) and committed basal ( $\mathrm{CB}, \mathrm{CD} 49 \mathrm{blo})$ populations. Benign $(\mathrm{Be}, \mathrm{n}=4)$ and malignant $(\mathrm{tnPCa}, \mathrm{n}=5)$ primary basal cells were isolated from tissue specimens of treatment-naïve PCa patients undergoing radical prostatectomy. All samples were grown in cell culture in vitro and SC/TIC, TA and CB subpopulations were isolated as previously described [43]. Samples were subjected to qRT-PCR analysis for MCL1. MCL1 mRNA expression was normalized to the housekeeper RPLP0 and is expressed as $2^{-\mathrm{dCt}}$. 
A LNCaP

LNCaP-abl

$\mathrm{VCaP}$

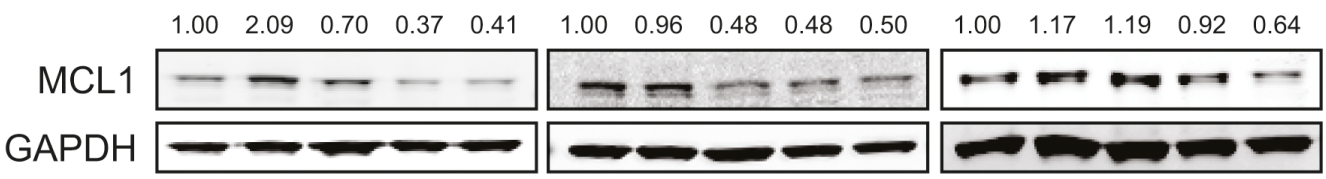

B

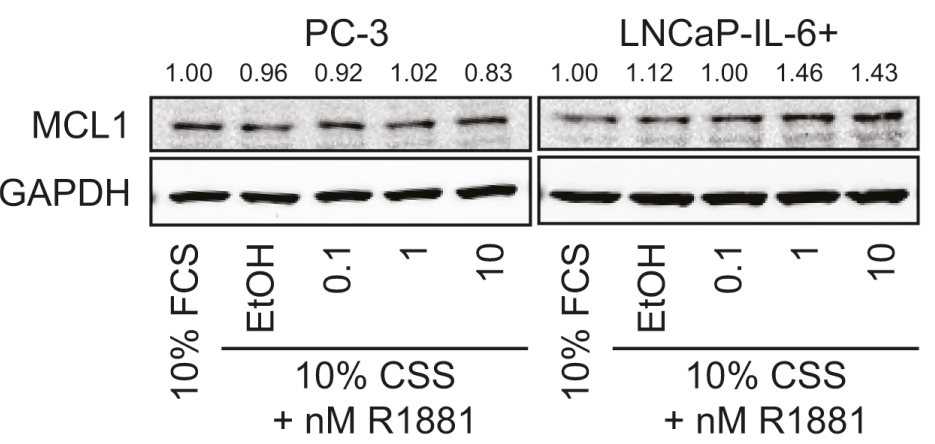
U 등
丩
ㅇํㅇ $10 \% \mathrm{CSS}$
$+\mathrm{nM}$ R1881

LNCaP

PC-3

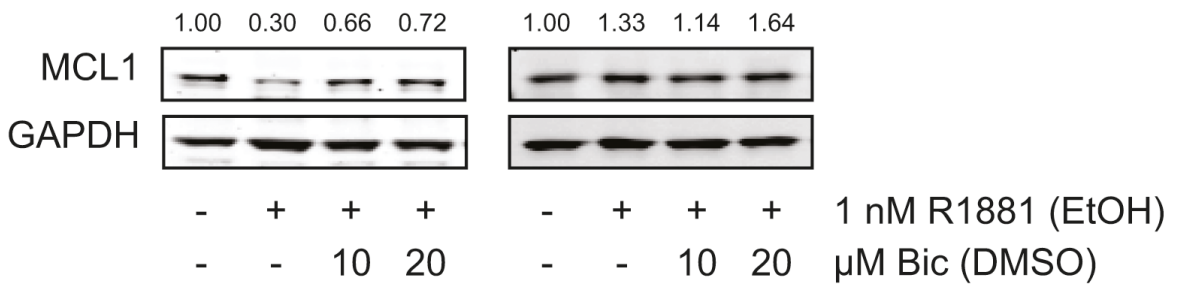

C
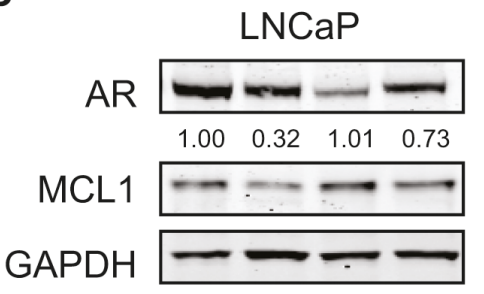

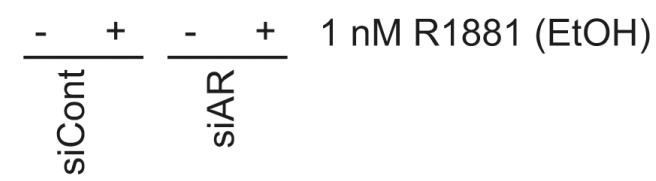

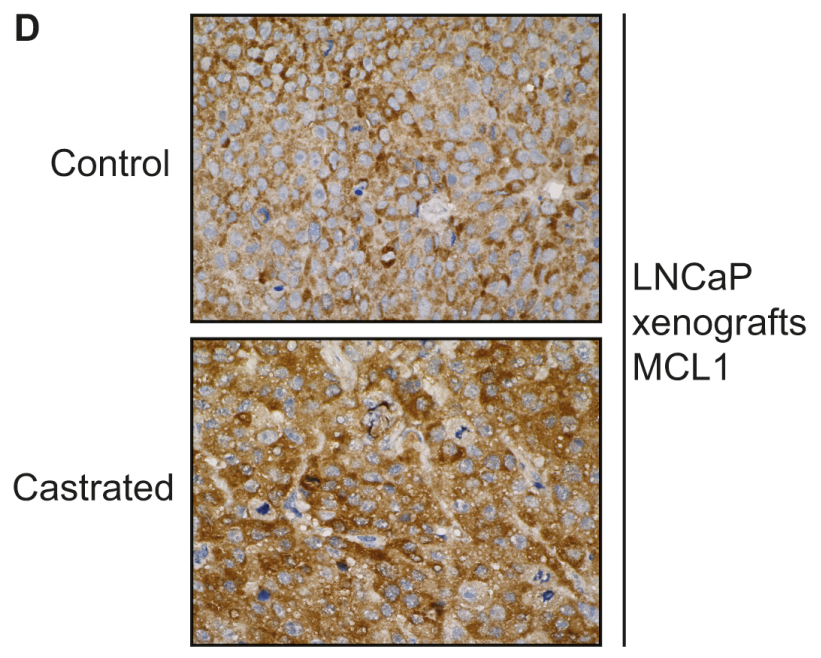

E

xenografts

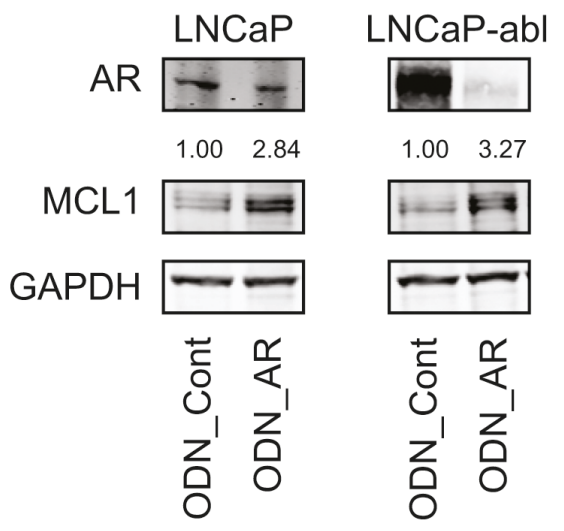




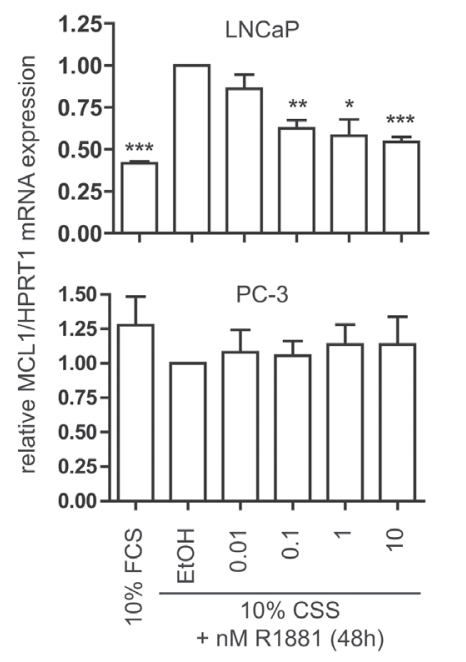

H

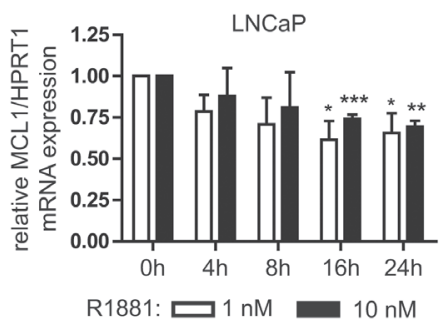

G

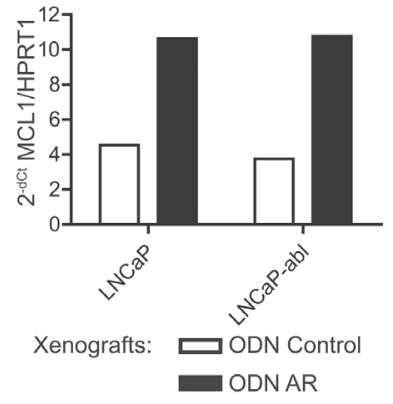

Figure 2: Androgenic regulation of MCL1 is dependent on functional AR and is a transcriptional mechanism. (A) Activation of the AR signaling axis through R1881 decreases MCL1 protein expression. PCa cell lines were steroid-deprived for $\geq 48 \mathrm{~h}$ using medium supplemented with $10 \%$ CSS and then treated for additional $48 \mathrm{~h}$ in medium supplemented with $10 \% \mathrm{FCS}$ or in medium supplemented with $10 \% \mathrm{CSS}$ and increasing concentrations of R1881 or vehicle (EtOH), as indicated. (B) Inhibition of AR by Bicalutamide counteracts the effects of R1881 on MCL1 expression. LNCaP and PC-3 were steroid-deprived for $\geq 48 \mathrm{~h}$ using medium supplemented with $10 \% \mathrm{CSS}$ and then treated for additional $48 \mathrm{~h}$ in medium supplemented with $10 \% \mathrm{CSS}$ and $1 \mathrm{nM}$ R1881 or vehicle (EtOH) with 10 or $20 \mu \mathrm{M}$ Bicalutamide (Bic) or vehicle (DMSO), as indicated. (C) Downregulation of AR by siRNA counteracts the effects of R1881 on MCL1 expression. LNCaP were steroid-deprived for $\geq 48 \mathrm{~h}$ using medium supplemented with $10 \% \mathrm{CSS}$ and then transfected with $30 \mathrm{nM}$ siRNA targeting AR (siAR) or control siRNA (siCont) and treated with $1 \mathrm{nM} \mathrm{R} 1881$ or vehicle (EtOH) for $48 \mathrm{~h}$, as indicated. (D) MCL1 expression is increased in LNCaP xenografts grown in castrated mice. LNCaP were implanted subcutaneously in both flanks of BALB/c nu/ nu mice. When tumors became palpable animals were castrated (6 animals, 12 tumors) or left intact (6 animals, 12 tumors). Tumors were explanted four weeks after castration and immunohistochemistry for MCL1 was performed on formalin-fixed, paraffin-embedded sections. Representative stainings for MCL1 of LNCaP xenografts from intact and castrated mice are shown. Statistical analysis of MCL1 intensities of intact vs. castrated animals showed mean intensity $(-/+\mathrm{SD})$ of $1.92(-/+0.29)$ vs. $2.25(-/+0.62) ; \mathrm{n}=12 ; \mathrm{p}=0.1026$, respectively. (E) MCL1 expression is increased in LNCaP and LNCaP-abl xenografts after downregulation of AR by oligodeoxynucleotides (ODN). LNCaP and LNCaP-abl were injected subcutaneously in intact or castrated BALB/c nu/nu mice, respectively. When tumors became palpable intraperitoneal injections with $5 \mathrm{mg} / \mathrm{kg}$ control oligodeoxynucleotides (ODN_Cont, $\mathrm{n}=6$ ) or $5 \mathrm{mg} / \mathrm{kg}$ ODN targeting the AR (ODN_AR, $\mathrm{n}=6$ ) were performed three times in the first week and twice in the following three weeks. After four weeks under this treatment protein was extracted from an explanted tumor from animals bearing LNCaP or LNCaP-abl xenografts transduced with either ODN_Cont or ODN_AR. (A-C, E) Protein expression was determined by immunoblotting using antibodies for AR, MCL1 and GAPDH, as indicated. Representative immunoblots are shown. Numbers indicate relative ratios of densitometrical analysis of MCL1 divided by the reference protein GAPDH. (F) MCL1 mRNA expression is regulated through the action of androgens. LNCaP and PC-3 cells were steroid-deprived for $\geq 48 \mathrm{~h}$ using medium supplemented with $10 \%$ CSS and then treated for additional $48 \mathrm{~h}$ with medium supplemented with $10 \%$ FCS or in medium supplemented with $10 \%$ CSS and increasing concentrations of R1881 or vehicle (EtOH), as indicated. (G) MCL1 mRNA is increased in LNCaP and LNCaP-abl xenografts transduced with ODN targeting the AR. From the animal experiment performed as described in (E) mRNA was extracted from an explanted tumor from animals bearing $\mathrm{LNCaP}$ or $\mathrm{LNCaP}$-abl xenografts receiving injections with control ODN (ODN_Cont) or AR ODN. (H) Androgenic regulation of MCL1 is significantly apparent after $16 \mathrm{~h}$ of incubation with R1881. LNCaP were steroid-deprived for $\geq 48 \mathrm{~h}$ using medium supplemented with $10 \% \mathrm{CSS}$ and then treated in medium supplemented with $10 \% \mathrm{CSS}$ and increasing concentrations of 1 or $10 \mathrm{nM} \mathrm{R} 1881$ or vehicle (EtOH) for different time points, as indicated. (F-H) MCL1 mRNA was quantified using qRT-PCR, normalized to the housekeeper HPRT1 and results are illustrated as relative mean $\pm \operatorname{SEM}, \mathrm{n} \geq 3$ (F, H) or in absolute values as $2^{\text {-dct }}(\mathrm{G})$. Statistical significances were calculated against EtOH-treated sample and encoded as follows: * $\mathrm{p}<0.05$; $* * \mathrm{p}<0.01 ; * * * \mathrm{p}<0.001$. 
protein levels after knock-down of three known E3ligases $\mathrm{APC} / \mathrm{C}^{\mathrm{CDC} 20}, \mathrm{SCF}^{\mathrm{FBXW} 7}$ and HUWE1 [18] (Fig. S1A). MCL1 mRNA was decreased in a dose-dependent manner through R1881 in LNCaP, while AR-negative PC-3 cells were unaffected. On the other hand, none of the three E3-ligases was able to antagonize the effect of R1881 on MCL1 protein expression. Similarly, the increased MCL1 protein expression seen in LNCaP and LNCaP-abl xenografts after knock-down of AR (Fig. 2E) was mediated by increased MCL1 mRNA expression (Fig. 2G). Time course experiments following addition of R1881 showed that androgenic repression of MCL1 was significant after $16 \mathrm{~h}$ at mRNA levels (Fig. 2H) and after $24 \mathrm{~h}$ at the protein level (Fig. S1B). Altogether, we concluded that androgenic signaling through the AR axis is able to repress MCL1 protein and mRNA expression.

\section{Androgenic repression of MCL1 is a cell cycle dependent mechanism}

Since decreased expression of MCL1 at the mRNA level was observable after 16 h R1881 treatment (Fig.
$2 \mathrm{H}$ ), we hypothesized that this regulation is not directly mediated by AR but rather indirectly by another ARstimulated transcription factor. Indeed, in a genome-wide chromatin-immunoprecipitation experiment coupled with deep sequencing (ChIP-seq) in DuCaP cells [19] we were not able to identify AR binding sites neighboring or within the MCL1 gene, in contrast to other known AR targets and, surprisingly, other BCL2 family members (Fig. 3A and S2A).

Activated AR is a potent stimulator of cell cycle progression from $\mathrm{G}_{1}$ to $\mathrm{S}$ phase in cancer cells through the Cyclin D1/retinoblastoma/E2F1 axis [2]. Previously, the cell cycle controller E2F1 was found to act as a repressor of the MCL1 promoter [20]. Thus, AR might repress MCL1 expression indirectly via E2F1 binding to the MCL1 promoter. We confirmed E2F1-binding to the MCL1 promoter in a ChIP experiment (Fig. 3B). E2F1 binding intensity to the MCL1 promoter was comparable to the known E2F1 target CDC2, however only mildly altered by the addition of R1881 implying that other cofactors regulating E2F1 transcriptional activity might be involved.
A

\begin{tabular}{|lll|}
\hline \multicolumn{3}{|c|}{ AR binding sequences } \\
\hline Gene & Alias & Fold \\
\hline BCL2L1 & BCLXL & 49,93 \\
BCL2L11 & BIM & 32,74 \\
BCL2L13 & MIL1 & 42,57 \\
BAK1 & BAK & 38,2 \\
BNIP3 & NIP3 & 20,01 \\
\hline KLK3 & PSA & 14,73 \\
TMPRSS2 & & 16,37 \\
\hline
\end{tabular}

B

\begin{tabular}{|ll|}
\hline \multicolumn{2}{|c|}{ no AR binding } \\
sequences \\
\hline Gene & Alias \\
\hline BCL2 & \\
BCL2L2 & BCL-W \\
MCL1 & \\
BCL2A1 & \\
BAX & \\
BOK & \\
BAD & \\
BID & \\
BIK & \\
HRK & HARAKIRI \\
BBC3 & PUMA \\
PMAIP1 & NOXA \\
BMF & \\
BCL2L10 & Diva \\
BCL2L14 & \\
BCL2L15 & Bfk \\
\hline
\end{tabular}

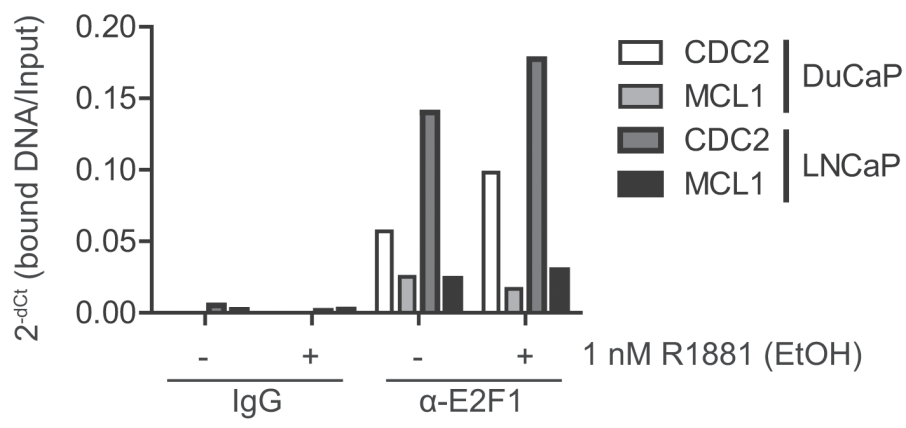



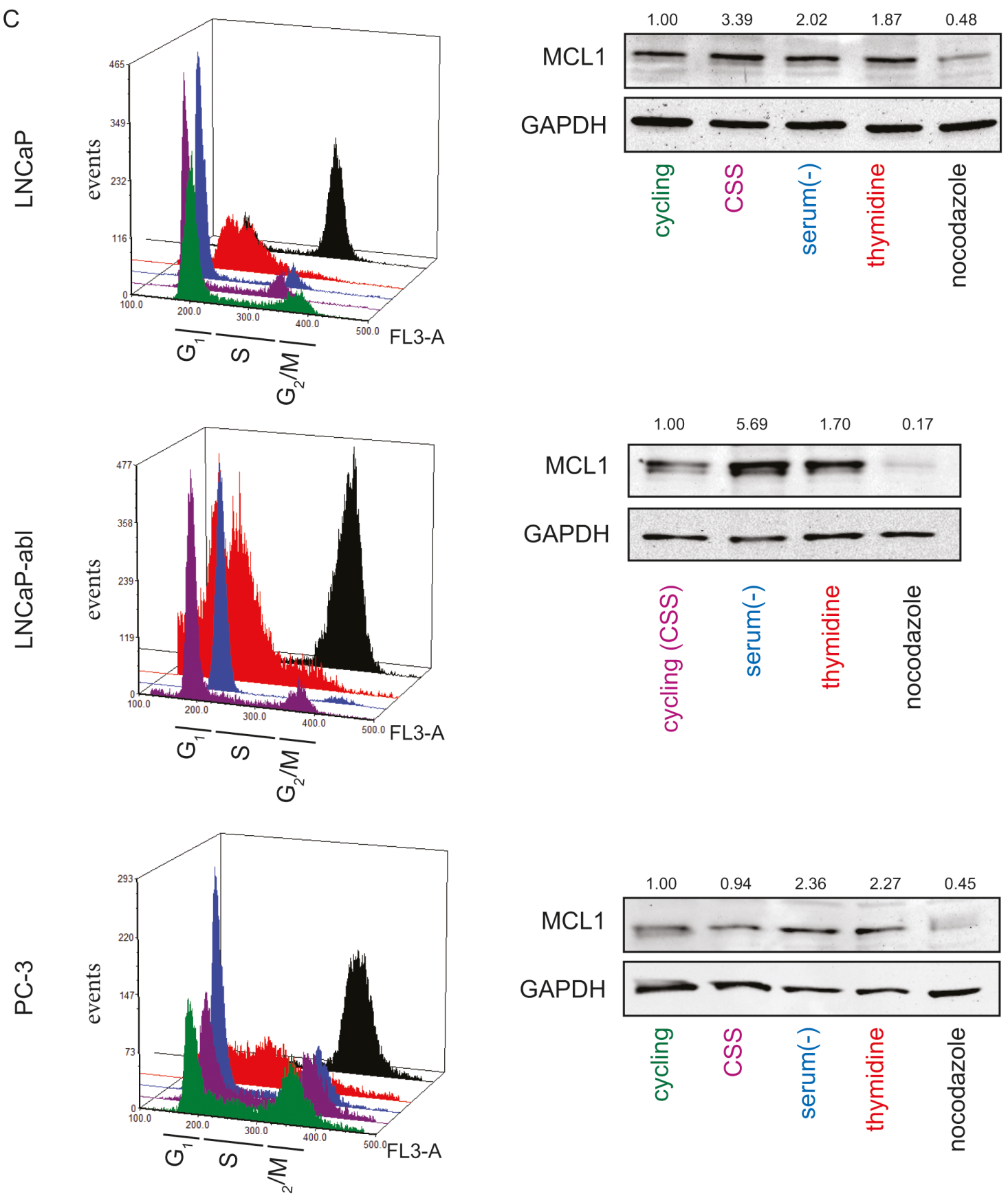

Figure 3: MCL1 is a cell cycle regulated protein. (A) The MCL1 gene locus does not contain AR binding sites. Chromatin immunoprecipitation (ChIP) was performed on DuCaP cells treated for $1 \mathrm{~h}$ with $1 \mathrm{nM} \mathrm{R} 1881$ or vehicle (EtOH) using anti-AR antibodies [19]. DNA bound to the precipitated AR complex was subjected to deep sequencing (ChIP-seq). The resulting gene list was searched for members of the BCL2 family and results are depicted in the tables. The fold change indicates the enrichment of AR bound to the respective sequence of R1881-treated versus vehicle-treated samples. Only the top fold regulation is shown. (B) The cell cycle regulatory transcription factor E2F1 binds to the promoter region of the MCL1 gene. DuCaP and LNCaP cells were steroid-deprived for $\geq 48 \mathrm{~h}$ using medium supplemented with 10\% CSS and then treated for additional $24 \mathrm{~h}$ in medium supplemented with $10 \%$ CSS and $1 \mathrm{nM}$ R1881 or vehicle (EtOH). ChIP was performed using antibodies against E2F1 or control isotype IgG. DNA bound by E2F1 or control IgG was quantified using primers against promoter regions of MCL1 or CDC2. Values were normalized to input taken before IP and are depicted as $2^{\text {-dCt }}$. (C) MCL1 is increasingly expressed in G1 and S phases, while decreased during G2/M. Various PCa cells were arrested in different cell cycle phases through complete serum deprivation $\left(\mathrm{G}_{1}\right.$, blue), excess of thymidine $\left(\mathrm{G}_{1} / \mathrm{S}\right.$, red $)$ and nocodazole treatment $\left(\mathrm{G}_{2} / \mathrm{M}\right.$, black). Additionally, normal proliferating cells (cycling, green) and steroid-deprived cells (10\% CSS, violet) are shown. LNCaP-abl cells actively proliferate in steroid-deprived medium. Histogram blots illustrate the distribution of cell cycle phases which was assessed by the DNA stain propidium iodide using flow cytometry. Representative immunoblots for MCL1 and GAPDH are shown. Numbers indicate relative ratios of densitometrical analysis of MCL1 divided by the reference protein GAPDH. 
Next, we analyzed whether increased expression levels of MCL1 through steroid-depletion could be mediated via a $G_{1}$ cell cycle arrest caused by the inactivation of AR. To this end, we arrested PCa cells in $\mathrm{G}_{1}, \mathrm{G}_{1} / \mathrm{S}$ and $\mathrm{G}_{2} / \mathrm{M}$ by serum withdrawal, thymidine excess and nocodazole treatment, respectively (Fig. 3C and S2B). Immunoblotting for MCL1 showed increased levels in $\mathrm{G}_{1}$ and $\mathrm{G}_{1} / \mathrm{S}$ phases, while, as previously published [21], decreased levels were detected after nocodazole treatment. This effect was observable in AR-positive and -negative cell lines showing that MCL1 levels could be increased by $\mathrm{G}_{1}$ cell cycle arrest independently of the AR status. In other words, androgenic regulation of MCL1 is an indirect mechanism through AR inactivation and consequent $G_{1}$ cell cycle arrest.

A

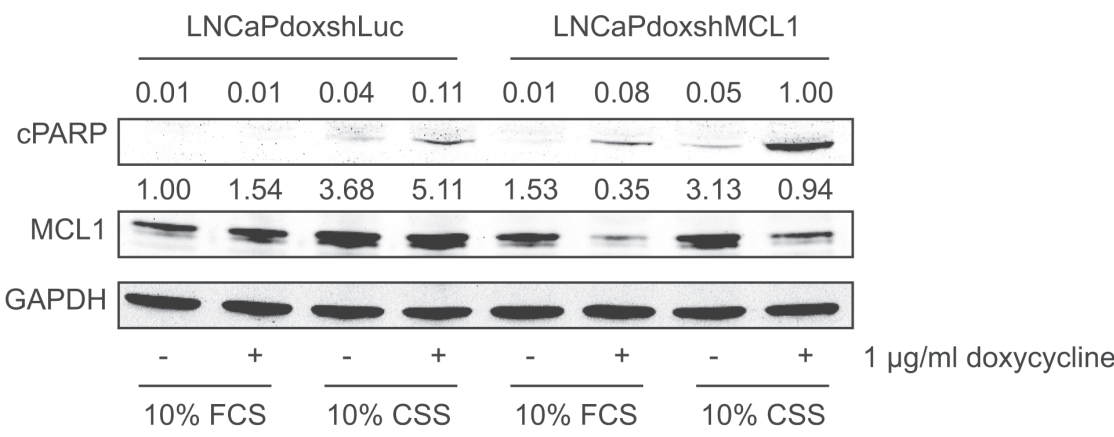

B
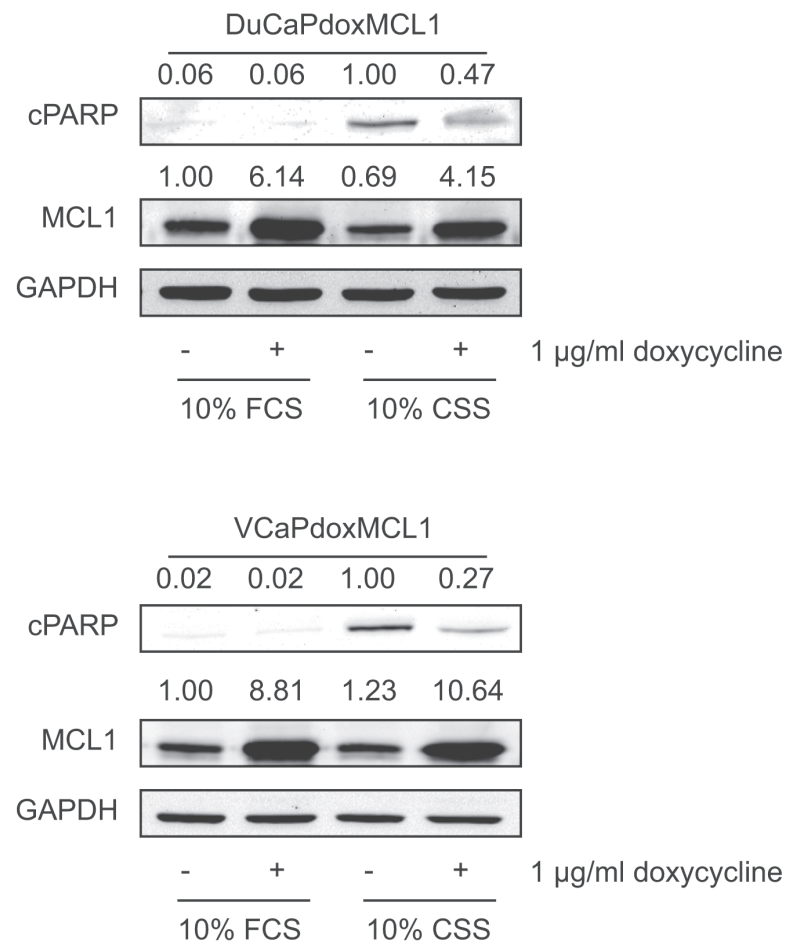

Figure 4: MCL1 protects cells from undergoing apoptosis under steroid-deprived conditions. (A) Knockdown of MCL1 in LNCaP cells leads to increased apoptosis under steroid-deprived conditions. LNCaP cells were stably transduced with doxycyclineregulated short hairpin (sh) constructs targeting MCL1 (LNCaPdoxshMCL1) or Luciferase (control, LNCaPdoxshLuc). Both cell lines were grown for $72 \mathrm{~h}$ under full medium conditions (10\% FCS) or under steroid-deprived conditions (10\% CSS) and expression of sh constructs was induced by addition of $1 \mu \mathrm{g} / \mathrm{ml}$ doxycycline, as depicted. (B) Overexpression of MCL1 rescues DuCaP and VCaP cells partially from undergoing apoptosis when grown in steroid-deprived conditions. DuCaP and VCaP were stably transduced with a doxycyclineregulated overexpression plasmid for MCL1 generating DuCaPdoxMCL1 and VCaPdoxMCL1. Both cell lines were grown for 40h under full medium conditions (10\% FCS) or under steroid-deprived conditions (10\% CSS) and overexpression of MCL1 was induced by addition of $1 \mu \mathrm{g} / \mathrm{ml}$ doxycycline. (A, B) Samples were analyzed by immunoblotting using antibodies against MCL1, cleaved PARP (cPARP, as an indicator for apoptosis) and GAPDH. Representative immunoblots are shown. Numbers indicate relative ratios of densitometrical analysis of MCL1 or cPARP divided by the reference protein GAPDH, respectively. 


\section{MCL1 protects PCa cells from undergoing apoptosis under steroid-depleted conditions}

Subsequently, we analyzed the functional role of MCL1 upregulation after AR inactivation and $G_{1}$ cell cycle arrest. $\mathrm{LNCaP}$ cells showed increased expression of MCL1 under steroid-deprived conditions but only a mild induction of apoptosis (Fig. 4A). To test the hypothesis that upregulated MCL1 protects $\mathrm{LNCaP}$ from undergoing apoptosis during steroid ablation we made use of a doxycycline-inducible short hairpin construct to downregulate MCL1 (shMCL1). While either steroid deprivation, or MCL1 downregulation under full growth conditions $(10 \%$ FCS) induced apoptosis only weakly, the combination of steroid deprivation and MCL1 downregulation resulted in a strong induction of apoptosis. In contrast, $\mathrm{DuCaP}$ and $\mathrm{VCaP}$ reacted with a strong apoptotic response to steroid ablation but only mild upregulation of MCL1 (Fig. 4B). Overexpression of MCL1 using doxycycline-inducible overexpression of MCL1 could partly rescue DuCaP and VCaP cells from undergoing apoptosis when grown in CSS-containing medium. In summary, our data shows that MCL1 acts as a pro-survival molecule under steroid-ablated conditions and, hence, targeting MCL1 might be a valuable addition to a steroid deprivation protocol.

\section{Induction of apoptosis after pharmacological inhibition of MCL1 is dependent on the progression state of PCa cells}

Based on the concept that MCL1 protects cells from undergoing apoptosis during steroid-deprived conditions, we compared the cell death inducing properties of the BH3-mimetic Obatoclax targeting MCL1 [10] under various conditions: a) full growth ( $10 \% \mathrm{FCS}), \mathrm{b})$ steroiddeprived (10\% CSS), c) activation of AR signaling (10\% CSS + $1 \mathrm{nM} \mathrm{R} 1881$ ), d) inactivation of AR signaling by the antagonist Bicalutamide (10\% CSS + $1 \mathrm{nM} \mathrm{R} 1881$ $+10 \mu \mathrm{M}$ Bic). When Obatoclax was tested on LNCaP and DuCaP cells, a concentration-dependent decrease of MCL1 expression levels was observed (Fig. 5A). As a consequence, apoptosis as evidenced by cPARP in immunoblots and cleaved caspase 3/7 activity assays, was increased. When tested under steroid-deprived conditions, DuCaP cells were significantly more susceptible for apoptosis induction by Obatoclax compared to full growth conditions and the same trend could be observed in LNCaP. Moreover, when tested under conditions where AR was activated or inactivated through R1881 or R1881 and Bicalutamide, respectively, Obatoclax showed higher efficiency when AR activity was blocked (Fig. 5B). The same experiments were repeated with the LNCaP-abl progression model (Fig. 5C and S3A). Immunoblots showed that Obatoclax was still able to decrease MCL1 expression levels, however, no significant induction of apoptosis could be observed. Experiments with the ARnegative PC-3 and LNCaP-IL-6+ revealed that both castration-resistant cell lines were refractory to apoptotic induction by Obatoclax up to $10 \mu \mathrm{M}$ (Fig. 5D and S3B). Only a mild induction of apoptosis was observable when Obatoclax concentration was increased up to $50 \mu \mathrm{M}$. Interestingly, a dose-dependent increase of MCL1 through Obatoclax treatment was detected. This suggests that MCL1 is a targetable molecule in early stage PCa.

\section{Obatoclax inhibits clonogenic potential of primary basal tnPCa cells}

Next, we tested whether primary basal, androgenindependent tnPCa cells would be sensitive to Obatoclax treatment. As previously found in cell lines (Fig. 5A, B), Obatoclax treatment led to a dose-dependent decrease of MCL1 expression levels, when cells were kept under full growth conditions (Fig. 6A). However, induction of apoptosis as evidenced by cPARP was not observable. Since increased MCL1 mRNA levels could be seen in TIC compared to benign SC (Fig. 1C), we assessed the reproductive integrity of tnPCa cells using clonogenic assays (Fig. 6B). When cells were seeded at low density, a decreased colony number was counted upon incubation with $0.1 \mu \mathrm{M}$ Obatoclax, while $1 \mu \mathrm{M}$ was sufficient to completely abolish clonogenic growth. This shows that Obatoclax is effective in inhibiting the reproductive integrity of primary basal tnPCa cells.

\section{DISCUSSION}

MCL1 has been proposed to have a unique role among the pro-survival members of the BCL2 family [5] that protect cells, and in particular cancer cells of diverse origins, against various anti-cancer treatments. For instance, high MCL1 expression in multiple myeloma was correlated with recurrence after chemotherapy and shorter survival [22] and mice bearing MCL1 overexpressing lymphomas were less sensitive to cyclophosphamide treatment in vivo [23]. Previously, we detected increased expression of MCL1 in docetaxel (Taxotere $^{\mathrm{TM}}$ )-resistant $\mathrm{PCa}$ cell lines, as well as in tissue derived from PCa patients after neoadjuvant docetaxel treatment [24]. Similarly, cisplatin-resistant cell lines of various tissue origins showed high expression of MCL1 compared to their sensitive counterparts, while BCL2 and BCL2L1 were up-regulated at low frequency [25]. This shows that MCL1 is a major mediator of resistance against chemotherapy. Here, we found that MCL1 is also protecting against the cell death-inducing effects of endocrine therapy. In fact, ADT-mediated $\mathrm{G}_{1}$ cell cycle arrest could be interpreted as a partial resistance mechanism to this therapy. Importantly, only surviving 

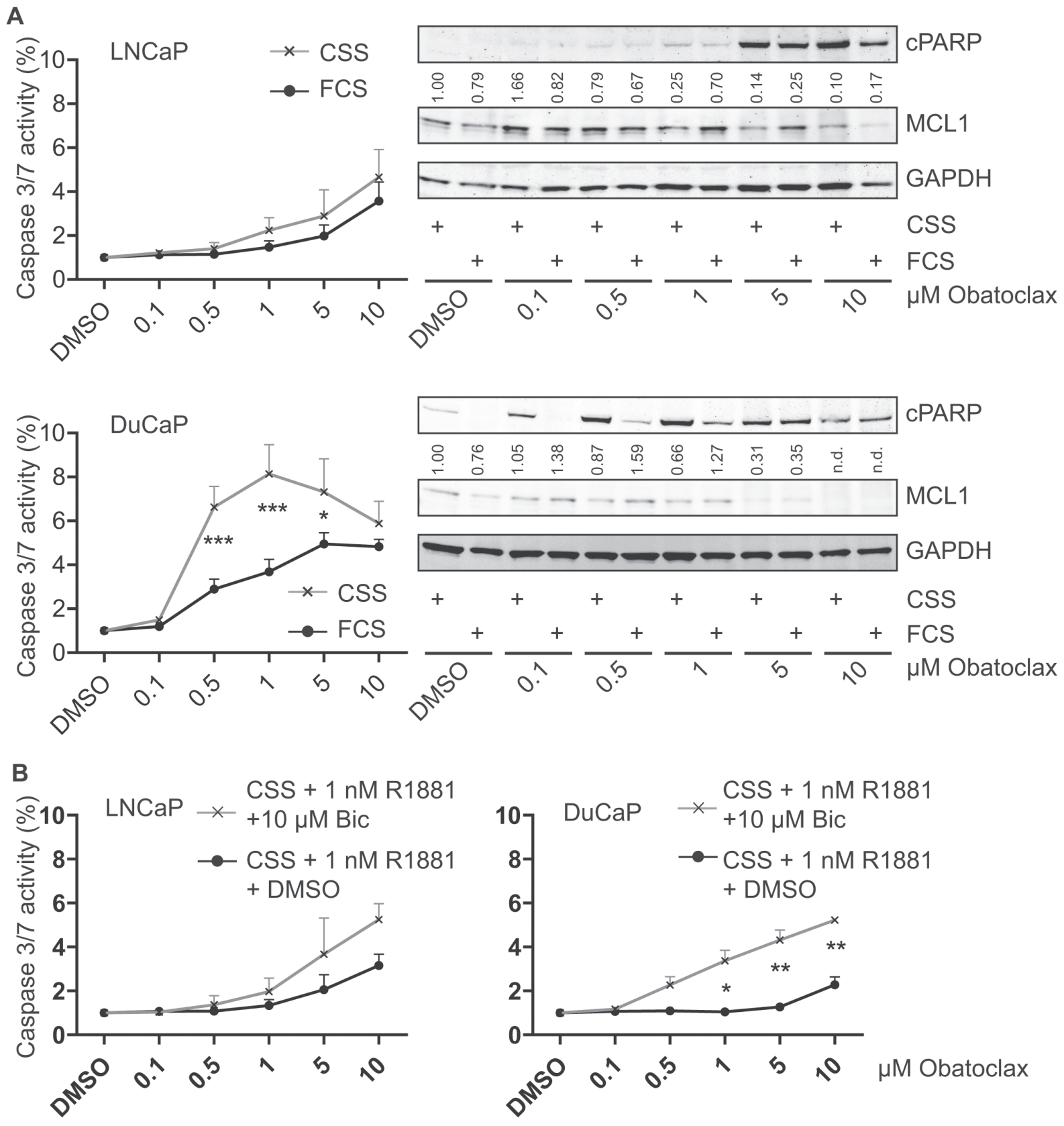

C
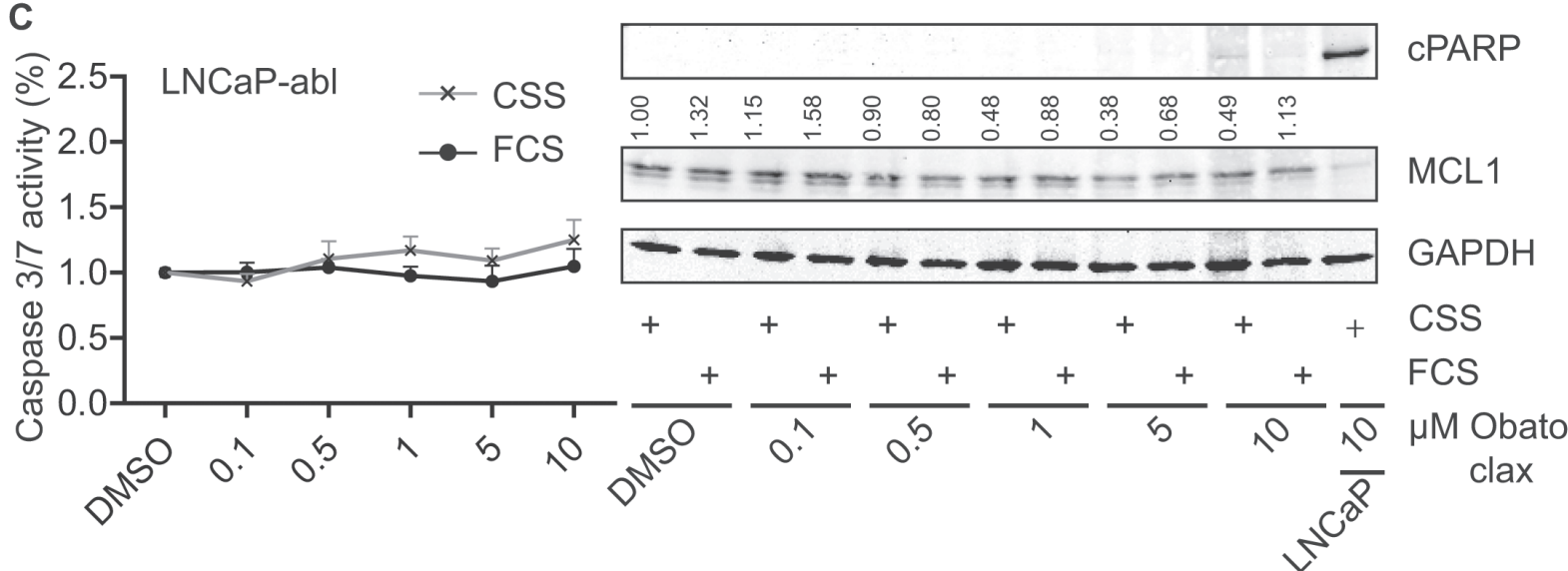


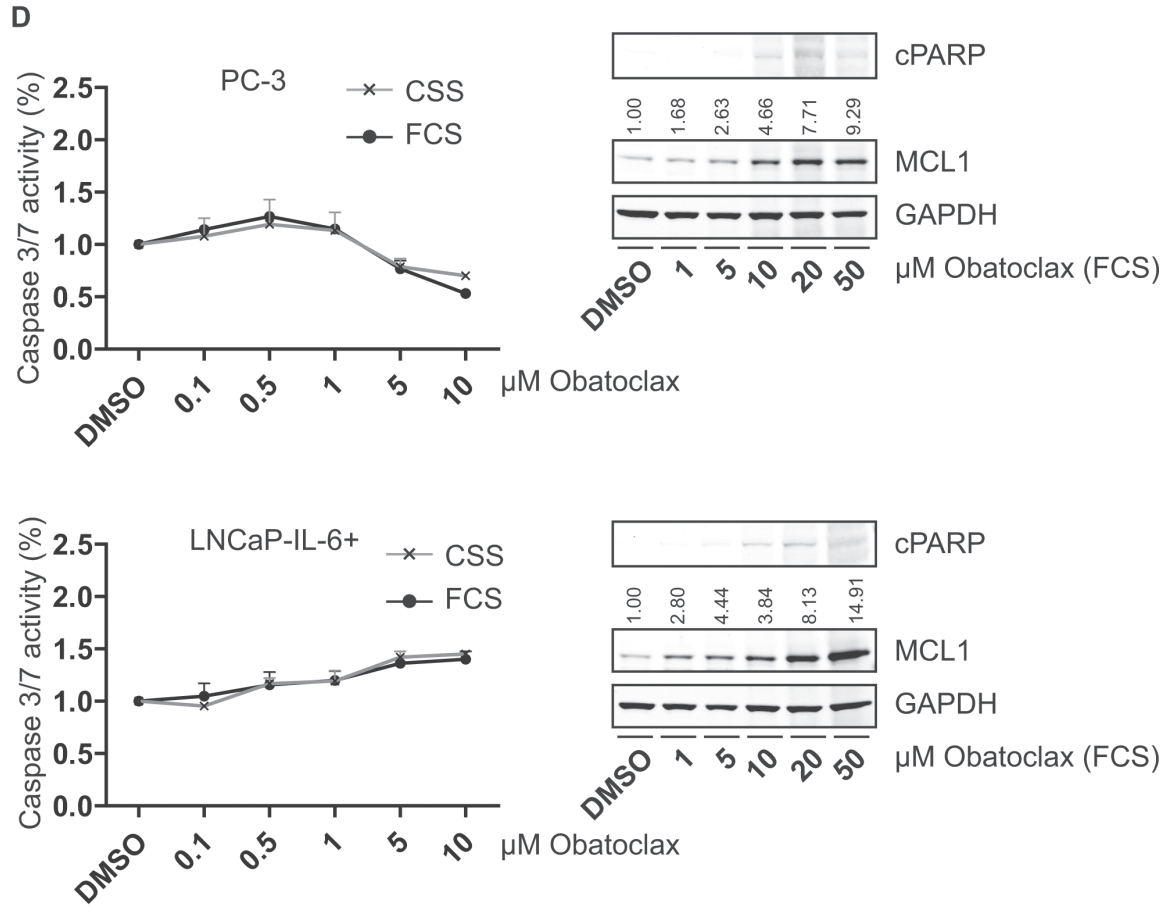

Figure 5: Obatoclax induces apoptosis in androgen-sensitive PCa cells but not in AR-negative PCa cells. (A, B) Steroiddeprivation or the AR antagonist Bicalutamide tend to potentiate the pro-apoptotic effect of Obatoclax in androgen-sensitive LNCaP and DuCaP cells. (C) Progressed LNCaP-abl cells are insensitive to Obatoclax. (D) Castration-resistant, AR-negative PC-3 and LNCaP-IL-6+ cells are resistant to apoptosis induction by Obatoclax and react to Obatoclax treatment by upregulating MCL1. (A, C-D) PCa cell lines were steroid-deprived for $\geq 48 \mathrm{~h}$ using medium supplemented with $10 \% \mathrm{CSS}$ and then treated for $24 \mathrm{~h}$ with increasing concentrations of Obatoclax or DMSO in medium containing $10 \%$ FCS or $10 \%$ CSS, as indicated. B) LNCaP and DuCaP were steroid-deprived for $\geq 48 \mathrm{~h}$ using medium supplemented with $10 \% \mathrm{CSS}$ and then treated for $24 \mathrm{~h}$ with increasing concentrations of Obatoclax or DMSO in medium containing 10\% CSS with the addition of $1 \mathrm{nM} \mathrm{R} 1881$ and $10 \mu \mathrm{M}$ Bicalutamide (Bic) or vehicle (DMSO), as indicated. (A-D) Graphs show relative activity of cleaved Caspase $3 / 7$ normalized to total protein. Additionally, immunoblotting was performed using antibodies detecting MCL1, cPARP and the reference protein GAPDH. Representative immunoblots are shown. Numbers indicate relative ratios of densitometrical analysis of MCL1 divided by the reference protein GAPDH. Significant differences were calculated between samples treated in medium supplemented with 10\% FCS versus 10\% CSS and samples treated in medium supplemented with $10 \%$ CSS and $1 \mathrm{nM}$ R1881 and $10 \mu \mathrm{M}$ Bicalutamide versus $10 \% \mathrm{CSS}$ and $1 \mathrm{nM} \mathrm{R} 1881$ and vehicle (DMSO). ${ }^{*} \mathrm{p}<0.05 ; * * * \mathrm{p}<0.001$

A

Figure 6: Obatoclax does not induce apoptosis in primary proliferating prostate cancer cells, while it is a potent inhibitor of clonogenicity. (A) Proliferating primary basal tnPCa cells are insensitive to Obatoclax treatment. Primary basal tnPCa cells were kept under proliferating conditions and incubated with increasing concentrations of Obatoclax for $24 \mathrm{~h}$. Immunoblotting was performed using antibodies detecting MCL1, cPARP and the reference protein GAPDH. A representative immunoblot from one out of three patients is shown. Numbers indicate relative ratios of densitometrical analysis of MCL1 divided by the reference protein GAPDH. (B) Obatoclax inhibits clonogenic growth of primary basal tnPCa cells. Primary basal tnPCa cells from three patients were seeded at low density $\left(30\right.$ cells $\left./ \mathrm{cm}^{2}\right)$ and treated in growth medium with increasing concentrations of Obatoclax or vehicle (DMSO) for 12 days. Mean colony number was calculated and depicted as relative surviving fraction for each patient.

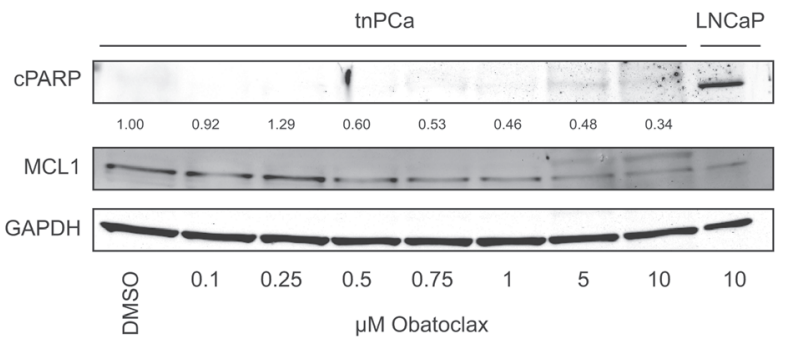

B

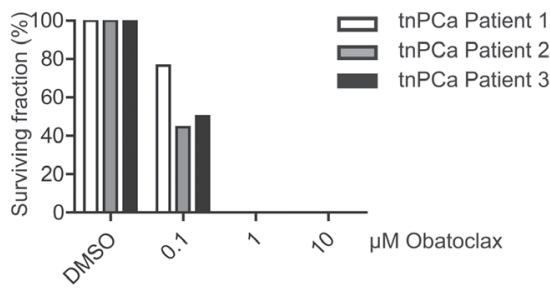


cells (i.e. complete ADT-unresponsive or ADT-cell cycle arrested cells) can be at the basis of a progression to a castration-resistant disease. In consequence, targeting MCL1 concurrent with an induction of apoptosis in the ADT-mediated cell cycle-arrested PCa cell population could prevent or delay development of castrationresistance.

The AR signaling axis and cell cycle progression are two closely interlinked cellular processes that mutually regulate each other [2]. After AR inactivation through steroid deprivation, increased expression of MCL1 was detectable in LNCaP, a cell line that reacts with $\mathrm{G}_{1}$ cell cycle arrest to AR inhibition [16,26,27]. On the other hand, a role for MCL1 as interacting partner of proliferating cell nuclear antigen (PCNA) was proposed to inhibit cell cycle progression in $\mathrm{S}$ phase [28]. During prolonged mitotic arrest MCL1 was found to be degraded and to induce apoptosis [21]. Furthermore, MCL1 promoted terminal mitosis and differentiation involving p2 $7^{\mathrm{KIP} 1}$ [29]. These examples show that the mutual interactions of $\mathrm{AR} /$ cell cycle/MCL1 signaling pathways in prostate cells result in a highly complex network. It is however unclear whether MCL1 is a regulator of cell cycle or whether MCL1 expression is regulated by cell cycle progression.

Pharmacological targeting of MCL1 by Obatoclax was efficient in androgen withdrawal-sensitive $\mathrm{LNCaP}$ and
DuCaP, but inefficient in androgen withdrawal-insensitive cells such as LNCaP-abl, PC-3 and LNCaP-IL-6+. This loss of cell death-inducing activity of Obatoclax could be due to decreased/absent expression of pro-apoptotic BAK1 and BAX, which was previously demonstrated in PC-3 cells [30]. Similar to our results in PCa cells, it was found that endoplasmic reticulum stress induced up-regulation of MCL1 and rendered melanoma cells more sensitive to Obatoclax treatment [31]. Furthermore, Obatoclax was able to induce apoptosis in primary chronic lymphocytic leukemia cells previously resistant to treatment with oncolytic vesicular stomatitis virus [32]. Sabutoclax, another BH3-mimetic targeting MCL1, could sensitize prostate cancer cells to IL-24 mediated cytotoxicity [33]. We deduce from these findings that MCL1 inhibition is acting as a secondary trigger to induce apoptosis in cells in which the primary treatment/trigger is insufficient to cause this effect. This might also explain the absent pro-apoptotic effect of Obatoclax on primary PCa cells (Fig. 6A), where Obatoclax was used as a single agent. Although the clinical development of Obatoclax has been discontinued during this study [34], our results may encourage further research into BCL2 family inhibitors, and in particular in small molecules targeting MCL1. For example, the recently identified hydroxyquinoline-derived compound 9, shows selective MCL1 inhibitory function
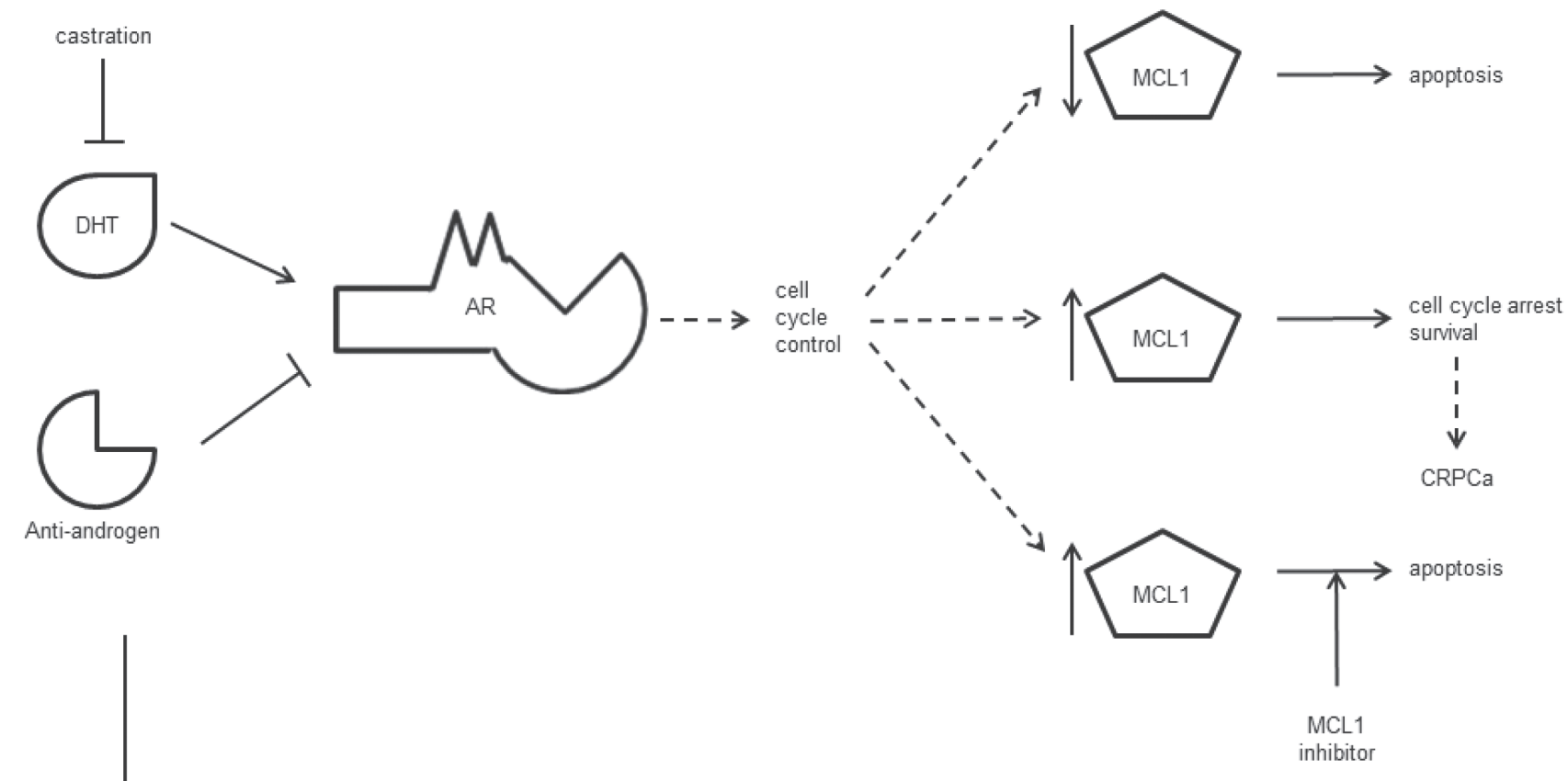

combination therapy

Figure 7: Schematic conclusion. AR activity may be inhibited by androgen withdrawal (castration) and/or anti-androgens that compete with the natural ligand dihydroxytestosterone (DHT) for binding. AR is an important controller of cell cycle progression. Upon AR inactivation, $\mathrm{PCa}$ cells undergo apoptosis (upper arrow) or induce a $\mathrm{G}_{1}$ cell cycle arrest concurrent with cell survival (middle arrow) and possible progression to CRPCa. Our data indicates that high expression of MCL1 protects PCa cells from undergoing apoptosis under these conditions. Thus, combination therapies targeting AR and MCL1 could improve the current ADT protocol (lower arrow). 
[35]. Possible clinical studies could select patients based on results of a $\mathrm{BH} 3$ profiling assay, which measures dependency of any or all anti-apoptotic BCL2 proteins for cellular survival [35].

High MCL1 expression was found in various cancer types [36]. In this study, we found a high expression of MCL1 by immunohistochemistry in the tissue of tnPCa patients (Fig. 1A, B), although we could not confirm a correlation of MCL1 staining score with Gleason score, as previously published [37]. Analysis of larger cohorts could clarify this discrepancy. Possible mechanistic explanations for increased MCL1 expression may be an amplification of the MCL1 gene locus, as detected in other cancer types [6] and cytokine and growth factor signaling resulting from tissue inflammation known to increase MCL1 expression [5]. Moreover, we detected also high MCL1 mRNA expression in the TIC populations from tnPCa samples (Fig. 1C). Similarly, MCL1 was found to be increasingly expressed in the side population of non-small cell lung cancer cell lines [38]. Intriguingly, inhibition of MCL1 by Obatoclax was able to suppress self-renewal of those cells, while we found that Obatoclax is also a potent inhibitor of PCa clonogenicity (Fig. 6B). In addition, overexpression of MCL1 was found to induce malignant transformation of hematopoietic stem cells [23]. In summary, this shows that MCL1 is increasingly expressed and plays a role in the fate of cells in several compartments within PCa tissue and indeed that it could play an important role in $\mathrm{PCa}$ tumor initiation.

In conclusion, we demonstrate that MCL1 is an important regulator of apoptosis in PCa cells. It is a mediator of immediate steroid-deprivation resistance in PCa cells that react with a $G_{1}$ cell cycle arrest to AR inactivation. Hence, our data provides a mechanistic rationale for considering clinical studies, where MCL1 inhibiting therapies could be assessed for synergy with the existing endocrine therapy for locally advanced and metastatic, hormone-sensitive PCa patients (Fig. 7).

\section{MATERIALS AND METHODS}

\section{Ethics statement}

Investigation has been conducted in accordance with the ethical standards and according to the Declaration of Helsinki and according to national and international guidelines and has been approved by the authors' institutional review board.

\section{Cell lines and culture}

Human PCa cell lines LNCaP, VCaP and PC-3 were obtained from ATCC (LCG Standards, Wesel, Germany), DuCaP were obtained from Prof. J. Schalken (Center for
Molecular Life Science, Nijmegen, The Netherlands) and were maintained as previously described [19]. The LNCaP sub-lines LNCaP-abl [16] and LNCaP-IL-6+ [17] were generated by long-term maintenance in medium containing 10\% charcoal-stripped serum (CSS, Hyclone, THP, Vienna, Austria) or in full growth medium containing $5 \mathrm{ng} / \mathrm{ml}$ interleukin-6 (IL-6), respectively. The following cell lines are androgen-sensitive and express AR: LNCaP, LNCaP-abl, VCaP and DuCaP. High passages $(>80)$ of LNCaP-IL-6+, as used in this study, and PC-3 are ARnegative and castration-resistant.

\section{Western blot}

Immunoblotting was performed as previously described [39]. The following antibodies were used: $\alpha$-MCL1 (1:500, S-19, Santa Cruz, Heidelberg, Germany); $\alpha$-glyceraldehyde-3-phosphate dehydrogenase (1:50 000, GAPDH, Merck Millipore, Darmstadt, Germany); $\alpha$-PARP p85 (cPARP, Promega, Mannheim, Germany).

\section{Quantitative Real-Time Polymerase Chain Reaction}

Quantitative Real-Time Polymerase Chain Reaction (qRT-PCR) was performed as previously described [40] using Taqman Gene Expression assays for MCL1 (Product number: Hs01050896_m1), HPRT1 (Hs02800695_ $\mathrm{m} 1$ ) and RPLP0 (Hs99999902_m1) (all from Life Technologies, Vienna).

\section{Caspase $3 / 7$ activity assays}

Activity of cleaved caspase $3 / 7$ was measured as previously described [41] using the Caspase 3/7-Glo assay (Promega) and normalized to protein input determined by BCA assay (ThermoScientific, Vienna).

\section{Immunohistochemistry}

Immunohistochemistry on a tissue micro array and on explanted xenografts was performed as previously described $[24,42]$ using $\alpha$-MCL1 (S-19, Santa Cruz).

\section{Primary basal cell culture}

Primary basal cell culture was performed in York (results in Fig. 1) and Innsbruck (results in Fig. 6). Permission for the use of patient specimens has been given by the Ethical Committees of Medical University of Innsbruck (Nr.:UN4837:317/4.7) and University of York (LREC ref No: 07/H1304/121). In York, isolation of primary basal cells was performed as previously described 
[43]. In Innsbruck, the protocol had to be adapted to the quantity of available tissue material derived from $3 \mathrm{~mm}$ needle biopsies using the "outgrowth" method. In brief, tissue from cancerous areas was collected by a needle biopsy on fresh prostate tissue after prostatectomy. Malignancy was confirmed by the uropathologist (G.S.) on a section of the needle biopsy taken before in vitro culture by routine diagnostics (haematoxylin and eosin, and p63/alpha-methylacyl-CoA racemase stainings). Tissue was then cut into small wedges which were put into a collagen I-coated T25 flask (Corning, Wiesbaden, Germany). Wedges were kept in K-SFM medium (Life Technologies, Vienna) supplemented with $2.5 \mu \mathrm{g} / 500 \mathrm{ml}$ EGF (Life Technologies), $25 \mathrm{mg} / 500 \mathrm{ml}$ bovine pituitary extract (Life Technologies), $2 \mathrm{ng} / \mathrm{ml}$ Leukemia inhibitory factor (Merck Millipore, Darmstadt), $2 \mathrm{ng} / \mathrm{ml}$ stem cell factor (Merck Millipore), $100 \mathrm{ng} / \mathrm{ml}$ cholera toxin (SigmaAldrich, Vienna), $1 \mathrm{ng} / \mathrm{ml}$ Granulocyte macrophage colony stimulating factor (Merck Millipore) and a mixture of $1 \mathrm{x}$ antibiotics and -mycotics (Life Technologies) until basal epithelial cells started to grow out from the wedges. At this timepoint STO mouse embryonal fibroblasts (ATCC, LCG Standards) previously irradiated with a dosis of 60 Gy were added to epithelial cells to form a confluent feeder layer. After one week tissue wedges were removed and the described procedure with the removed wedges was repeated twice more. Epithelial cells were grown until $80 \%$ confluence and passaged by trypsinization or seeded into collagen I-coated (BD Biosciences, Heidelberg) 6-wells for experiments. Stem/Tumor-initiating (SC/TIC), transit amplifying (TA) and committed basal (CB) cells were isolated as previously described [43].

\section{Cell cycle analysis}

The following treatments were performed to arrest cells in different cell cycle phases: a) cycling: normal growth conditions (medium containing 10\% CSS for LNCaP-abl or medium containing 10\% FCS for all other cell lines); b) CSS, $\mathrm{G}_{1}$ : incubation with medium containing $10 \%$ CSS for 3 days; c) serum(-), $G_{1}$ : incubation with medium without addition of serum for 3 days; d) thymidine $\mathrm{G}_{1} / \mathrm{S}$ : incubation in normal growth medium and $10 \mathrm{mM}$ thymidine for 3 days; e) nocodazole, $\mathrm{G}_{2} / \mathrm{M}$ : incubation in normal growth medium and $200 \mathrm{ng} / \mathrm{ml}$ nocodazole for 18 hours. Cells were then harvested using a cell scraper, fixed in 70:30 (v/v) ethanol:PBS at $4^{\circ} \mathrm{C}$, and digested with $50 \mu \mathrm{g} / \mathrm{ml}$ RNase A (Roche, Vienna) for $30 \mathrm{~min}$ at room temperature. Cells were stained with 50 $\mu \mathrm{g} / \mathrm{ml}$ propidium iodide in PBS. Cell cycle distribution was analyzed using the FL3-A channel of a FACSCalibur (BD Biosciences) and visualized using FCS Express Flow Cytometry 4 software (De Novo Software, Glendale, CA, USA). Doublets were discriminated by plotting FL3-A events against FL3-W and gating for singlets.

\section{Animal experiments}

Animal protocols were approved by the Austrian Federal Ministry for Education, Science and Culture (BMWF-66.011/0130-II/10b/2009, BMWF-66.011/0116$\mathrm{II} / 3 \mathrm{~b} / 2011)$. Xenografted tumors were grown by subcutaneous implantation of a $0.1 \mathrm{ml}$ suspension of $2 \times 10^{6}$ LNCaP cells mixed with $0.1 \mathrm{~mL}$ matrigel (BD Biosciences) into both, the right and the left flanks of anesthetized male nude mice (BALB/c/nu/nu, 4-6 weeks old, Charles River Laboratories, Sulzfeld, Germany), respectively. When the tumors became palpable, mice were randomly divided into three different treatment groups: ODN_Ctrl (5 mg/kg body weight), ODN_AR ( $5 \mathrm{mg} / \mathrm{kg}$ body weight) and castration. Oligonucleotides (ODNs) with 2'-O-(2-methoxy)ethyl modifications at the $5^{\prime}$ and $3^{`}$ ends, respectively, and phosphorothioated internucleotide linkages were purchased from GenXpress (VWR, Vienna): ODN_AR 5'-*u*g*c*ugaagagtagc*a*g

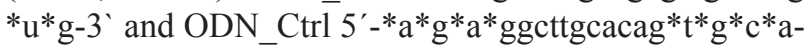
$3^{\prime}$ (modified bases are indicated by an asterisk). Castration was performed by orchiectomy of anesthetized mice. ODNs were dissolved in $0.9 \%(\mathrm{w} / \mathrm{v})$ sodium chloride solution and administered intraperitoneally at a final concentration of $5 \mathrm{mg} / \mathrm{kg}$ mouse three times in the first week and twice from week 2 to 4 . Explanted tumors were subdivided into two pieces and either frozen in liquid nitrogen for Western blot analysis or fixed in buffered formalin $(4.5 \%)$ and embedded in paraffin for further immunohistochemical staining and qRT-PCR. LNCaP-abl cells $\left(2 \times 10^{6}\right.$ cells mixed with matrigel in a 1:1 ratio) were injected into mice that received orchiectomy one week before.

\section{Clonogenic assay}

Primary basal cells were trypsinized, counted and plated in full growth medium at a density of 30 cells/ $\mathrm{cm}^{2}$ (equals 300 cells per 6-well) in triplicates. Irradiated STO feeder cells were added to form a confluent layer (as described above). Treatment with Obatoclax (0.1 $10 \mu \mathrm{M}$ ) or DMSO (vehicle) was performed on the day after seeding the cells. Medium was renewed every 2-3 days with new addition of Obatoclax and STO feeder cells. Colonies were stained as previously described [42]. Plating efficiency in DMSO treated samples was calculated by the number of colonies divided by number of cells seeded. Survival fraction was calculated by dividing the number of colonies by the product of plating efficiency and cells seeded. 


\section{Chemicals}

The synthetic androgen R1881 (methyltrienolone) was purchased from Organon (MSD, Vienna) and dissolved in ethanol at stock concentrations of $0.1,1$, and $10 \mu \mathrm{M}$. Bicalutamide $\left(\right.$ Casodex $^{\mathrm{TM}}$ ) was obtained from AstraZeneca (Macclesfield, UK) and dissolved in DMSO at a stock concentration of $10 \mathrm{mM}$. Obatoclax mesylate was purchased from Selleckchem.com (Eubio, Vienna) and dissolved in DMSO at a stock concentration of 10 $\mathrm{mM}$.

\section{Chromatin immunoprecipitation}

$\mathrm{DuCaP}$ and $\mathrm{LNCaP}$ were cultured for two days under steroid deprived conditions using medium containing $10 \%$ CSS. Cells were then treated in medium containing 10\% CSS with addition of $1 \mathrm{nM} \mathrm{R} 1881$ or vehicle $(\mathrm{EtOH})$. For chromatin immunoprecipitation the ChIPAb+E2F-1 kit from Merck Millipore was used following the manufacturer's instructions. QRT-PCR was performed on immunoprecipitated DNA and inputs using the following primer pairs: E2F-1 binding site on Mcl-1 promoter: forward 5'-cge cce ttt ccc ctt tta tgg-3' and reverse 5'- gaa gac ccc gac tcc tta ctg g-3' (derived from [20]). CDC2 primers were provided with the kit. Normalization was done using the formula $2^{-\mathrm{dCt}}$ where $\mathrm{dCt}$ was calculated as the difference between $\mathrm{Ct}($ immunoprecipitation) and $\mathrm{Ct}$ (input).

\section{Transfections, lentiviral infections and plasmids}

PCa cell lines were transfected using Lipofectamine 2000 (Life Technologies) as previously described [41]. For downregulation of CDC20, FBXW7 and HUWE1 ON-TARGET plus smart pools consisting of four specific siRNA sequences and non-targeting control ONTARGET plus smart pool (Dharmacon, ThermoScientific) were used and cells were transfected at a concentration of $50 \mathrm{nM}$. AR was downregulated by transfection of $30 \mathrm{nM}$ with the following annealed constructs: sense 5'-GCACUGCUACUCUUCAGCAdTdT-3' and antisense 5'-UGCUGAAGAGUAGCAGUGCdTdT-3', as previously described [44].

The lentiviral plasmid for conditional MCL1 silencing was generated by GATEWAYbased recombination of sequence verified pENTR-THT-MCL1 [45] (targeting sequence 5'-CCATTAGCAGAAAGTATCA-3' cloned into pENTRTHT-I) with pGLTR-X [46]. The generation of lentiviral plasmid for conditional MCL1 (pHR-tetCMV-hMCLires-GFP) was described elsewhere [45]. pHR-SFFVrtTA-M2-T2A-Puro was made by amplifying rtTA2-M2 from pLIB-rtTA2-M2-ires-Puro [47] introducing a T2A sequence by T2A-sequence modified antisense primer. In a second reaction the puromycin $\mathrm{N}$-acetyl transferase (pac) gene [48] was amplified using T2A-sequence modified sense primer. The PCR-products of both reactions were mixed and used as template for the third reaction using the rtTA2-M2 sense- and the puromycin antisense primer. The final $1.52 \mathrm{~kb}$ PCR product was purified, digested with BamHI and NotI and cloned into the BamHI/NotI site of pHR-SIN-CSGW (kindly provided by Mary Collins, UCL, London, UK) exchanging the eGFP with the rtTA2-M2T2A-Puro cassette. The sequence verified plasmid was used to generate lentiviral particles.

Lentiviral infection of target cells was performed as described previously [45]. In brief, confluent HEK293T were transfected with $1.5 \mu \mathrm{g}$ lentiviral vector, 0.9 $\mu \mathrm{g}$ pSPAX2 packaging and $0.9 \mu \mathrm{g}$ pMD-G VSV-Gpseudotyping plasmids (both vectors were kindly provided by D. Trono, EPFL, Lausanne, Switzerland) by calcium phosphate-based transfection. Target cells were infected using $0.45 \mu \mathrm{m}$ filtered virus containing cell culture supernatant obtained at 48 and 72 hours after transfection and supplemented with $1 \mu \mathrm{g} / \mathrm{ml}$ polybrene (SigmaAldrich). For conditional overexpression, cells were infected with lentiviral vectors encoding sequences for rtTA2-M2, followed by selection of puromycin $(1 \mu \mathrm{g} / \mathrm{ml})$. Puromycin resistant cells were superinfected with pHR-tetCMVhMCL1-ires-GFP [45].

\section{Statistical analysis}

The statistical significances of differences between treatment and control samples were calculated with Student's t-test using Graph Pad Prism. Comparison groups are given in the figures and/or figure legends and significances are encoded as follows: ${ }^{*} \mathrm{p}<0.05 ;{ }^{* *} \mathrm{p}<0.01$; $* * * p<0.001$. Statistical significances of differences in Fig. 1B and 2D have been calculated with Mann-Whitney U-test using Graph Pad Prism and p values are indicated in the figure or figure legend.

\section{ACKNOWLEDGEMENTS}

This project was funded by Austrian National Bank (grant 13952 to Z.C.), Austrian Science Fund FWF (grants L544 and W1101 to Z.C., and P267990 to F.R.S.), the Competence Center Oncotyrol (project 3.4) within the scope of the Austrian Competence Center for Excellent Technologies (COMET) - program conducted by the Austrian Research Promotion Agency (FFG) (to I.E.E.), the Austrian Cancer Society/Tyrol (to F.R.S). We are thankful for excellent technical assistance from Karin Unterberger, Susanne Lobenwein, Irma Sottsas, Gabriele Dobler and Fabian Guggenberger. 


\section{Conflict of interest}

The authors declare no conflict of interest.

\section{REFERENCES}

1. Heidenreich A, Bastian PJ, Bellmunt J, Bolla M, Joniau $\mathrm{S}$, van der Kwast $\mathrm{T}$, Mason M, Matveev V, Wiegel T, Zattoni F, Mottet N, European Association of Urology. EAU guidelines on prostate cancer. Part II: Treatment of advanced, relapsing, and castration-resistant prostate cancer. Eur Urol. 2014; 65: 467-479.

2. Balk SP, Knudsen KE. AR, the cell cycle, and prostate cancer. Nucl Recept Signal. 2008; 6.

3. Volkmann N, Marassi FM, Newmeyer DD, Hanein D. The rheostat in the membrane: BCL-2 family proteins and apoptosis. Cell Death Differ. 2014; 21: 206-215.

4. Willis SN, Chen L, Dewson G, Wei A, Naik E, Fletcher JI, Adams JM, Huang DCS. Proapoptotic Bak is sequestered by $\mathrm{Mcl}-1$ and $\mathrm{Bcl}-\mathrm{xL}$, but not Bcl-2, until displaced by BH3-only proteins. Genes Dev. 2005; 19: 1294-1305.

5. Perciavalle RM, Opferman JT. Delving deeper: MCL-1's contributions to normal and cancer biology. Trends in Cell Biology. 2013; 23: 22-29.

6. Beroukhim R, Mermel CH, Porter D, Wei G, Raychaudhuri S, Donovan J, Barretina J, Boehm JS, Dobson J, Urashima M, Mc Henry KT, Pinchback RM, Ligon AH, et al. The landscape of somatic copy-number alteration across human cancers. Nature. 2010; 463: 899-905.

7. Konopleva M, Contractor R, Tsao T, Samudio I, Ruvolo PP, Kitada S, Deng X, Zhai D, Shi Y-X, Sneed T, Verhaegen M, Soengas M, Ruvolo VR, et al. Mechanisms of apoptosis sensitivity and resistance to the $\mathrm{BH} 3$ mimetic ABT-737 in acute myeloid leukemia. Cancer Cell. 2006; 10: $375-388$.

8. Hermanson DL, Das SG, Li Y, Xing C. Overexpression of Mcl-1 confers multidrug resistance, whereas topoisomerase II $\beta$ downregulation introduces mitoxantrone-specific drug resistance in acute myeloid leukemia. Mol Pharmacol. 2013; 84: 236-243

9. Mazumder S, Choudhary GS, Al-Harbi S, Almasan A. Mcl1 Phosphorylation defines ABT-737 resistance that can be overcome by increased NOXA expression in leukemic B cells. Cancer Res. 2012; 72: 3069-3079.

10. Nguyen M, Marcellus RC, Roulston A, Watson M, Serfass L, Murthy Madiraju SR, Goulet D, Viallet J, Bélec L, Billot $\mathrm{X}$, Acoca S, Purisima E, Wiegmans A, et al. Small molecule obatoclax (GX15-070) antagonizes MCL-1 and overcomes MCL-1-mediated resistance to apoptosis. Proc Natl Acad Sci USA. 2007; 104: 19512-19517.

11. Trudel S, Li ZH, Rauw J, Tiedemann RE, Wen XY, Stewart AK. Preclinical studies of the pan-Bcl inhibitor obatoclax (GX015-070) in multiple myeloma. Blood. 2007; 109: 5430-5438.
12. Brem EA, Thudium K, Khubchandani S, Tsai P-C, Olejniczak SH, Bhat S, Riaz W, Gu J, Iqbal A, Campagna R, Knight J, Mavis C, Hoskin P, et al. Distinct cellular and therapeutic effects of obatoclax in rituximab-sensitive and -resistant lymphomas. Br J Haematol. 2011; 153: 599-611.

13. Chiappori AA, Schreeder MT, Moezi MM, Stephenson JJ, Blakely J, Salgia R, Chu QS, Ross HJ, Subramaniam DS, Schnyder J, Berger MS. A phase I trial of pan-Bcl-2 antagonist obatoclax administered as a 3-h or a 24-h infusion in combination with carboplatin and etoposide in patients with extensive-stage small cell lung cancer. Br J Cancer. 2012; 106: 839-845.

14. Oldridge EE, Pellacani D, Collins AT, Maitland NJ. Prostate cancer stem cells: are they androgen-responsive? Mol Cell Endocrinol. 2012; 360: 14-24.

15. Pellacani D, Oldridge EE, Collins AT, Maitland NJ. Prominin-1 (CD133) Expression in the Prostate and Prostate Cancer: A Marker for Quiescent Stem Cells. Adv Exp Med Biol. 2013; 777: 167-184.

16. Culig Z, Hoffmann J, Erdel M, Eder IE, Hobisch A, Hittmair A, Bartsch G, Utermann G, Schneider MR, Parczyk K, Klocker H. Switch from antagonist to agonist of the androgen receptor bicalutamide is associated with prostate tumour progression in a new model system. Br J Cancer. 1999; 81: 242-251.

17. Hobisch A, Ramoner R, Fuchs D, Godoy-Tundidor S, Bartsch G, Klocker H, Culig Z. Prostate cancer cells (LNCaP) generated after long-term interleukin 6 (IL6) treatment express IL-6 and acquire an IL-6 partially resistant phenotype. Clin Cancer Res. 2001; 7: 2941-2948.

18. Mojsa B, Lassot I, Desagher S. Mcl-1 Ubiquitination: Unique Regulation of an Essential Survival Protein. Cells. 2014; 3: 418-437.

19. $\mathrm{Bu} \mathrm{H}$, Schweiger MR, Manke $\mathrm{T}$, Wunderlich A, Timmermann B, Kerick M, Pasqualini L, Shehu E, Fuchsberger C, Cato ACB, Klocker H. Anterior gradient 2 and 3--two prototype androgen-responsive genes transcriptionally upregulated by androgens and by oestrogens in prostate cancer cells. FEBS J. 2013; 280: 1249-1266.

20. Croxton R, Ma Y, Song L, Haura EB, Cress WD. Direct repression of the Mcl-1 promoter by E2F1. Oncogene. 2002; 21: 1359-1369.

21. Millman SE, Pagano M. MCL1 meets its end during mitotic arrest. EMBO Rep. 2011; 12: 384-385.

22. Wuillème-Toumi S, Robillard N, Gomez P, Moreau P, Le Gouill S, Avet-Loiseau H, Harousseau J-L, Amiot M, Bataille R. Mcl-1 is overexpressed in multiple myeloma and associated with relapse and shorter survival. Leukemia. 2005; 19: 1248-1252.

23. Campbell KJ, Bath ML, Turner ML, Vandenberg CJ, Bouillet P, Metcalf D, Scott CL, Cory S. Elevated Mcl1 perturbs lymphopoiesis, promotes transformation of hematopoietic stem/progenitor cells, and enhances drug 
resistance. Blood. 2010; 116: 3197-3207.

24. Puhr M, Hoefer J, Neuwirt H, Eder IE, Kern J, Schäfer G, Geley S, Heidegger I, Klocker H, Culig Z. PIAS1 is a crucial factor for prostate cancer cell survival and a valid target in docetaxel resistant cells. Oncotarget. 2014.

25. Michels J, Obrist F, Vitale I, Lissa D, Garcia P, BehnamMotlagh P, Kohno K, Wu GS, Brenner C, Castedo M, Kroemer G. MCL-1 dependency of cisplatin-resistant cancer cells. Biochem Pharmacol. 2014; 92: 55-61.

26. Hobisch A, Fritzer A, Comuzzi B, Fiechtl M, Malinowska K, Steiner H, Bartsch G, Culig Z. The androgen receptor pathway is by-passed in prostate cancer cells generated after prolonged treatment with bicalutamide. Prostate. 2006; 66: 413-420.

27. Pignatta S, Arienti C, Zoli W, Di Donato M, Castoria G, Gabucci E, Casadio V, Falconi M, De Giorgi U, Silvestrini R, Tesei A. Prolonged exposure to (R)bicalutamide generates a LNCaP subclone with alteration of mitochondrial genome. Mol Cell Endocrinol. 2014; 382: 314-324.

28. Fujise K, Zhang D, Liu J, Yeh ETH. Regulation of Apoptosis and Cell Cycle Progression by MCL1 DIFFERENTIAL ROLE OF PROLIFERATING CELL NUCLEAR ANTIGEN. J Biol Chem. 2000; 275: 39458 39465.

29. Hasan SMM, Sheen AD, Power AM, Langevin LM, Xiong J, Furlong M, Day K, Schuurmans C, Opferman JT, Vanderluit JL. Mcl1 regulates the terminal mitosis of neural precursor cells in the mammalian brain through p27Kip1. Development. 2013; 140: 3118-3127.

30. Parrondo R, de Las Pozas A, Reiner T, Perez-Stable C. ABT-737, a small molecule Bcl-2/Bcl-xL antagonist, increases antimitotic-mediated apoptosis in human prostate cancer cells. PeerJ. 2013; 1: e144.

31. Jiang CC, Lucas K, Avery-Kiejda KA, Wade M, deBock CE, Thorne RF, Allen J, Hersey P, Zhang XD. Upregulation of Mcl-1 Is Critical for Survival of Human Melanoma Cells upon Endoplasmic Reticulum Stress. Cancer Res. 2008; 68: 6708-6717.

32. Samuel S, Tumilasci VF, Oliere S, Liên-Anh Nguyên T, Shamy A, Bell J, Hiscott J. VSV Oncolysis in Combination With the BCL-2 Inhibitor Obatoclax Overcomes Apoptosis Resistance in Chronic Lymphocytic Leukemia. Mol Ther. 2010; 18: 2094-2103.

33. Dash R, Azab B, Quinn BA, Shen X, Wang X-Y, Das SK, Rahmani M, Wei J, Hedvat M, Dent P, Dmitriev IP, Curiel DT, Grant S, et al. Apogossypol derivative BI-97C1 (Sabutoclax) targeting Mcl-1 sensitizes prostate cancer cells to mda-7/IL-24-mediated toxicity. Proc Natl Acad Sci USA. 2011; 108: 8785-8790.

34. Williams R. Discontinued drugs in 2012: oncology drugs. Expert Opin Investig Drugs. 2013; 22: 1627-1644.

35. Richard DJ, Lena R, Bannister T, Blake N, Pierceall WE, Carlson NE, Keller CE, Koenig M, He Y, Minond D,
Mishra J, Cameron M, Spicer T, et al. Hydroxyquinolinederived compounds and analoguing of selective Mcl-1 inhibitors using a functional biomarker. Bioorg Med Chem. 2013; 21: 6642-6649.

36. Quinn BA, Dash R, Azab B, Sarkar S, Das SK, Kumar S, Oyesanya RA, Dasgupta S, Dent P, Grant S, Rahmani M, Curiel DT, Dmitriev I, et al. Targeting Mcl-1 for the therapy of cancer. Expert Opin Investig Drugs. 2011; 20: 1397-1411.

37. Krajewska M, Krajewski S, Epstein JI, Shabaik A, Sauvageot J, Song K, Kitada S, Reed JC. Immunohistochemical analysis of bcl-2, bax, bcl-X, and mcl-1 expression in prostate cancers. Am J Pathol. 1996; 148: 1567-1576.

38. Singh S, Bora-Singhal N, Kroeger J, Laklai H, Chellappan SP. $\beta$ Arrestin-1 and Mcl-1 Modulate Self-Renewal Growth of Cancer Stem-Like Side-Population Cells in Non-Small Cell Lung Cancer. PLoS ONE. 2013; 8: e55982.

39. Cavarretta IT, Neuwirt H, Untergasser G, Moser PL, Zaki MH, Steiner H, Rumpold H, Fuchs D, Hobisch A, Nemeth JA, Culig Z. The antiapoptotic effect of IL-6 autocrine loop in a cellular model of advanced prostate cancer is mediated by Mcl-1. Oncogene. 2007; 26: 2822-2832.

40. Erb HHH, Langlechner RV, Moser PL, Handle F, Casneuf T, Verstraeten K, Schlick B, Schäfer G, Hall B, Sasser K, Culig Z, Santer FR. IL6 sensitizes prostate cancer to the antiproliferative effect of IFN 22 through IRF9. Endocr Relat Cancer. 2013; 20: 677-689.

41. Santer FR, Höschele PPS, Oh SJ, Erb HHH, Bouchal J, Cavarretta IT, Parson W, Meyers DJ, Cole PA, Culig Z. Inhibition of the acetyltransferases p300 and CBP reveals a targetable function for $\mathrm{p} 300$ in the survival and invasion pathways of prostate cancer cell lines. Mol Cancer Ther. 2011; 10: 1644-1655.

42. Hoefer J, Schäfer G, Klocker H, Erb HHH, Mills IG, Hengst L, Puhr M, Culig Z. PIAS1 is increased in human prostate cancer and enhances proliferation through inhibition of p21. Am J Pathol. 2012; 180: 2097-2107.

43. Collins AT, Berry PA, Hyde C, Stower MJ, Maitland NJ. Prospective identification of tumorigenic prostate cancer stem cells. Cancer Res. 2005; 65: 10946-10951.

44. Desiniotis A, Schäfer G, Klocker H, Eder IE. Enhanced antiproliferative and proapoptotic effects on prostate cancer cells by simultaneously inhibiting androgen receptor and cAMP-dependent protein kinase A. Int J Cancer. 2010; 126: 775-789.

45. Ploner C, Rainer J, Niederegger H, Eduardoff M, Villunger A, Geley S, Kofler R. The BCL2 rheostat in glucocorticoidinduced apoptosis of acute lymphoblastic leukemia. Leukemia. 2008; 22: 370-377.

46. Sigl R, Ploner C, Shivalingaiah G, Kofler R, Geley S. Development of a multipurpose GATEWAY-based lentiviral tetracycline-regulated conditional RNAi system (GLTR). PLoS ONE. 2014; 9: e97764. 
47. Ausserlechner MJ, Obexer P, Deutschmann A, Geiger K, Kofler R. A retroviral expression system based on tetracycline-regulated tricistronic transactivator/repressor vectors for functional analyses of antiproliferative and toxic genes. Mol Cancer Ther. 2006; 5: 1927-1934.

48. De la Luna S, Ortín J. pac gene as efficient dominant marker and reporter gene in mammalian cells. Meth Enzymol. 1992; 216: 376-385. 